\title{
Natural and human-induced Holocene paleoenvironmental changes on the Guadiana shelf (northern Gulf of Cadiz)
}

\author{
I Mendes,' JA Dias, ' J Schönfeld, ${ }^{2}$ Ó Ferreira,' F Rosa, ' R Gonzalez, ${ }^{3}$ and FJ Lobo ${ }^{4}$
}

\begin{abstract}
Three contrasting sedimentary environments on the continental shelf off the Guadiana River (northern Gulf of Cadiz) were integrated in a chronological framework and analysed in terms of sedimentology and benthic foraminiferal assemblages to understand the Holocene paleoenvironmental evolution. The analysed environments differ in terms of their depositional regimes and benthic foraminiferal assemblages. However, a dominant fluvial origin of the sand fraction was observed in all three environments. Holocene sedimentary processes were mainly controlled by natural (sea level changes and climate variations) and human-induced processes (e.g. deforestation, agriculture) along four evolutionary stages. The three older stages were mainly influenced by natural processes, such as sea level variations and fluvial inputs, whereas the most recent stage reflects a combination of climatic- and human-induced processes. A deepening of sedimentary environments related to a period of rapid sea level rise, strongly influenced by river discharges occurred from c. II,500 to c. 10,000 cal. yr BP. A reduction in sediment export to the shelf, as a result of the continuous and rapid sea level rise and enhanced estuary infilling reflects the second stage, from c. 10,000 to c. 5000 cal. yr BP. The beginning of the third stage, from c. 5000 to c. I500-I000 cal. yr BP, is marked by a sea-level slowdown and the relatively stable climate and environmental conditions. The fourth stage, from c. I500-I000 cal. yr BP to Recent times, reflects the intensification of human-induced processes and climatic variability in the Guadiana River basin. This stage also reflects modern depositional conditions, with the formation of a proximal prodeltaic wedge and a distal muddy body.
\end{abstract}

\section{Keywords}

anthropogenic impact, benthic foraminifera, climate change, continental shelf, Gulf of Cadiz, Holocene

Received I9 May 20II; revised manuscript accepted I3 December 201 I

\section{Introduction}

Shelf sediment sequences are recognized as important environmental archives, as they respond not only to a number of natural processes such as sea level fluctuations, and oceanographic and climatic changes, but also to the most recent anthropogenic impacts (e.g. Bauch et al., 2001; Evans et al., 2002; Lesueur et al., 1996; Mendes et al., 2010; Oldfield et al., 2003). The drastic changes in sea level observed within the Holocene, combined with local factors, resulted in the generation of both transgressive and highstand sediment bodies. Additionally, the combined influence of climatic and oceanographic changes promoted significant variations in sediment supply. Shelf depositional systems responded to these changes, as evidenced by shifting depositional and erosional areas. Such environments have been additionally influenced during the last centuries by human-induced processes (e.g. Dias et al., 2004; Fletcher et al., 2007; Gonzalez et al., 2005; Nocete et al., 2005).

Benthic foraminifera are the principal microfossils used in the reconstruction of past sea-floor conditions, because of their wide distribution in both space and geological time, and also because of their rapid response to ecological changes (Murray, 2006). In addition, benthic foraminifera can be used: (1) to date the sediments where they lived, providing a relative timescale (e.g. Evans et al., 2002; Oldfield et al., 2003; Scourse et al., 2002; Xiang et al., 2008); (2) in the interpretation of depositional patterns (e.g. Hald et al., 1999; Kaminski et al., 2002; Martins et al., 2007; Wollenburg et al., 2007); (3) to recognize different environments (e.g. Jiang et al., 1997; Martins et al., 2006; Morigi et al., 2005; Rossi and Vaiani, 2008); (4) as proxies of several parameters such as dissolved oxygen, organic production, salinity, and temperature (e.g. Abrantes et al., 2005; Altenbach and Sarnthein, 1989; Diz et al., 2002; Kaiho, 1999).

Despite the aforementioned studies, integrated approaches concerning Holocene paleoenvironmental changes in shelves environment are scarce (e.g. Lesueur et al., 1996; Martins et al., 2006; Mendes et al., 2010). Thus, the main goal of this study is to understand the Holocene paleoenvironmental changes of the continental shelf in the vicinity of the Guadiana River, in terms of the evolution of depositional patterns in response to natural processes (such as sea level changes, fluvial inputs, climatic variations) and human-induced environmental changes. For this purpose, sedimentological and benthic foraminiferal analyses, integrated in a temporal framework, were performed on three cores retrieved from distinct depositional environments.

'CIMA, Universidade do Algarve, Portugal

${ }^{2}$ Helmholtz-Zentrum für Ozeanforschung Kiel (GEOMAR), Germany

${ }^{3}$ Institute of Geography, Geography/Urban and Regional Studies, Switzerland

${ }^{4}$ Instituto Andaluz de Ciencias de la Tierra (CSIC-Universidad de Granada), Spain

\section{Corresponding author:}

I Mendes, CIMA, Universidade do Algarve, Edifício 7, Campus de Gambelas, 8005-I 39 Faro, Portugal.

Email: imendes@ualg.pt 


\section{Study area}

The study area is located on the northern Gulf of Cadiz continental shelf (southwestern Iberian Peninsula) off the Guadiana River mouth (Figure 1). This area receives the discharges from the Guadiana River, which is the main sediment source. Its annual mean water discharge $\left(80 \mathrm{~m}^{3} / \mathrm{s}\right)$ is about half of the Guadalquivir River discharge (van Geen et al., 1997) and the estimated sediment supply to the shelf between 1946 and 1990 was $57.90 \times 10^{4} \mathrm{~m}^{3} / \mathrm{yr}$ for average suspended load and $43.96 \times 10^{4} \mathrm{~m}^{3} / \mathrm{yr}$ for bedload (Morales, 1997). Its river basin, the fourth largest on the Iberian Peninsula, is highly susceptible to climatic variability, showing strong inter- and intra-annual variations in rainfall (Loureiro et al., 1986). Furthermore, the area is also subject to the influence of larger-scale annual and decadal climatic signals such as the North Atlantic Oscillation (NAO), as revealed in data for rainfall and river discharge (e.g. Dias et al., 2004; Trigo et al., 2004). These strong variations in climatic conditions can result in episodic floods that play a major role in the supply of sediment to the continental shelf (Morales, 1997; Portela, 2006). The coast off Guadiana River is considered mesotidal, with a mean range of $2 \mathrm{~m}$ (e.g. Morales, 1997). The offshore waves are predominately from the west-southwest $(71 \%$ of occurrences), but easterly winds frequently generate short-period waves incoming from the southeast (23\% of occurrences) (Costa et al., 2001). Wave energy is moderate with an average annual significant offshore wave height of $1.0 \mathrm{~m}$ and average peak period of $8.2 \mathrm{~s}$ (Costa et al., 2001). Storm events in the region have been defined with offshore wave heights $>3 \mathrm{~m}$ (Pessanha and Pires, 1981). Between 1986 and 1993, storm events accounted for $1 \%$ of the offshore wave climate (Costa, 1994).

The postglacial evolution of depositional systems was strongly influenced by rapid changes in sea level, leading to the formation of high-frequency transgressive and highstand system tracts (Lobo et al., 2001, 2004). Three transgressive parasequences exposed across the inner to middle shelf were identified in high-resolution seismic profiles (Lobo et al., 2001). Highstand deposits occur on the inner shelf as a prodeltaic wedge and on the middle shelf as an extensive muddy belt (Gonzalez et al., 2004; Lobo et al., 2004; Nelson et al., 1999). Recent studies have characterized the geochemical, micropaleontological, and sedimentological properties of those highstand deposits (e.g. Burdloff et al., 2008; Corredeira et al., 2008; Mendes et al., 2006, 2010; Rosa et al., 2011).

Climatic variations together with human activities initiated environmental changes in the Guadiana basin after c. 4000 cal. yr BP (Fletcher et al., 2007). During the late pre-Roman, Roman, Moorish and early Portuguese stages of settlement (which correspond to the period between c. 3000 and c. $300 \mathrm{yr} \mathrm{BP}$ ), exploitation for timber and other agricultural products caused widespread erosion and siltation of estuaries (Chester and James, 1999). In the upper estuary, widespread erosion and soil loss caused by overuse of land suggests abandonment of rural villages during the mid-12th century (Boone and Worman, 2007). These anthropogenic influences have significantly increased in both intensity and scale during the last 150 years, namely through mining and agriculture activities with consequent deforestation, and the construction of dams in the river basin, which have affected the amount of sediment supplied to the shelf (Dias et al., 2004; Gonzalez and Dias, 2006; Gonzalez et al., 2001; Maldonado and Nelson, 1999).

\section{Material and methods}

Cores were collected from the continental shelf off the Guadiana River in July 2002 (Figure 1), by using a light-weighted vibrocorer with water injection. Core 5 with $353 \mathrm{~cm}$ length was collected from a central position in the muddy body at a water depth of $72 \mathrm{~m}$ (latitude $37^{\circ} 1^{\prime} 54^{\prime \prime} \mathrm{N}$ and longitude $7^{\circ} 20^{\prime} 44^{\prime \prime} \mathrm{W}$ ). Core 7 with 71.5 cm length was taken at $36 \mathrm{~m}$ water depth $\left(37^{\circ} 3^{\prime} 44^{\prime \prime} \mathrm{N}, 7^{\circ} 17^{\prime} 40^{\prime \prime} \mathrm{W}\right)$ within the proximal zone of a transgressive sandy deposit. Core 8 with $376 \mathrm{~cm}$ length was extracted from the inner shelf Guadiana prodeltaic wedge, at a water depth of $22 \mathrm{~m}\left(37^{\circ} 7^{\prime} 24^{\prime \prime} \mathrm{N}, 7^{\circ} 16^{\prime} 6^{\prime \prime} \mathrm{W}\right)$ (Figure 1). Mud sediment cores (5 and 8) were sampled continuously in intervals of $1 \mathrm{~cm}$ thick slices from the top down to $50 \mathrm{~cm}$ and in intervals of $2 \mathrm{~cm}$ slices from there to the base. Core 7 was sampled in intervals of $1 \mathrm{~cm}$ thick slices from the top down to $4 \mathrm{~cm}$ and from 26 to $50 \mathrm{~cm}$, and in intervals of $2 \mathrm{~cm}$ thick slices in the remaining intervals of the core, which consisted of coarser sediments. Each level of cores 7 and 8 was sampled for grain size and benthic foraminiferal analyses. Core 5 was sampled on alternating levels for grain size and benthic foraminifera, in order to obtain more material for each analysis.

Eleven accelerated mass spectrometry (AMS) radiocarbon $\left({ }^{14} \mathrm{C}\right.$ ) dates were obtained (Table 1 ) by using benthic foraminiferal test mixtures of most abundant species, carried out by Beta Analytic (USA). The age calibration was made with the program Calib 5.1 (Stuiver et al., 2005), by using the MARINE 04 curve with a global ocean reservoir correction of about 400 years (Stuiver and Reimer, 1993). The local reservoir effect $(\Delta R)$ was applied according to Soares and Martins (2010) (Table 1). Two additional amino acid racemisation (AAR) dates were performed on samples from core 5 (Table 1). The analyses were performed by the Amino Acid Geochronology Laboratory of the Northern Arizona University, USA.

The age model was created based on ${ }^{14} \mathrm{C}$ and AAR calibrated ages ( 2 sigma) (Table 1), depth, and sedimentation rates, assuming a constant rate of accumulation between the dated levels. The zero validation for the age model was applied.

Grain size analyses were performed sequentially along the cores. When available material was not enough, two or more adjacent samples were combined for one grain size analysis. Hydrogen peroxide was used to eliminate organic matter. Fine (silt and clay) and coarse (sand and gravel) fractions were wet separated using a $63 \mu \mathrm{m}(4 \varphi)$ sieve. The fine fraction was analysed using the pipette method and the coarse fraction was subdivided by dry sieving using a sieve rack. Both fractions were graded in phi intervals. The textural classification was performed according to Folk (1954).

Components of the sand fraction were analysed in the three cores at irregular intervals, varying from 1 to $10 \mathrm{~cm}$. A total of 71 , 27 , and 38 samples were analysed in cores 5,7 , and 8 , respectively. Data used for core 8 were adapted from Pinheiro et al. (2006). In each phi grade of the sand fraction, 100 grains were counted and identified. For each sample the weighted mean for each grain type was calculated after Sarnthein (1971).

Benthic foraminifera were analysed in core 5 for 41 samples (collected from the core with a variable spacing of 2 to $12 \mathrm{~cm}$ ), in core 7 for 15 samples (variable spacing of 4 to $6 \mathrm{~cm}$ ), and in core 8 for 38 samples $(10 \mathrm{~cm}$ intervals). The material $>63 \mu \mathrm{m}$ was divided in aliquots by using an Otto micro-splitter, placed in a picking tray, and analysed under a binocular microscope. Whenever possible, at least 300 well-preserved benthic foraminiferal tests were collected from each sample, identified, and counted. Benthic foraminifera were classified according to the generic classification of Loeblich and Tappan (1987), and determined by reference to Ellis and Messina (1942-2009), Murray (1971), Jones (1994), Levy et al. (1995), and Martins and Gomes (2004). The Diversity Shannon Index was calculated by using PAST software (PAlaeontological STatistics, ver. 1.81; Hammer et al., 2008). Zonation areas were constructed by using the Psimpoll 4.25 program (Bennett, 2005). The method of binary splitting by information content was used. Cluster analyses were also performed using PAST software (Hammer et al., 2008). For each core, a matrix of data was built using species with more than $5 \%$ abundance in at least one sample. R-mode cluster analyses grouped species by using the correlation method and joined the groups by using the 


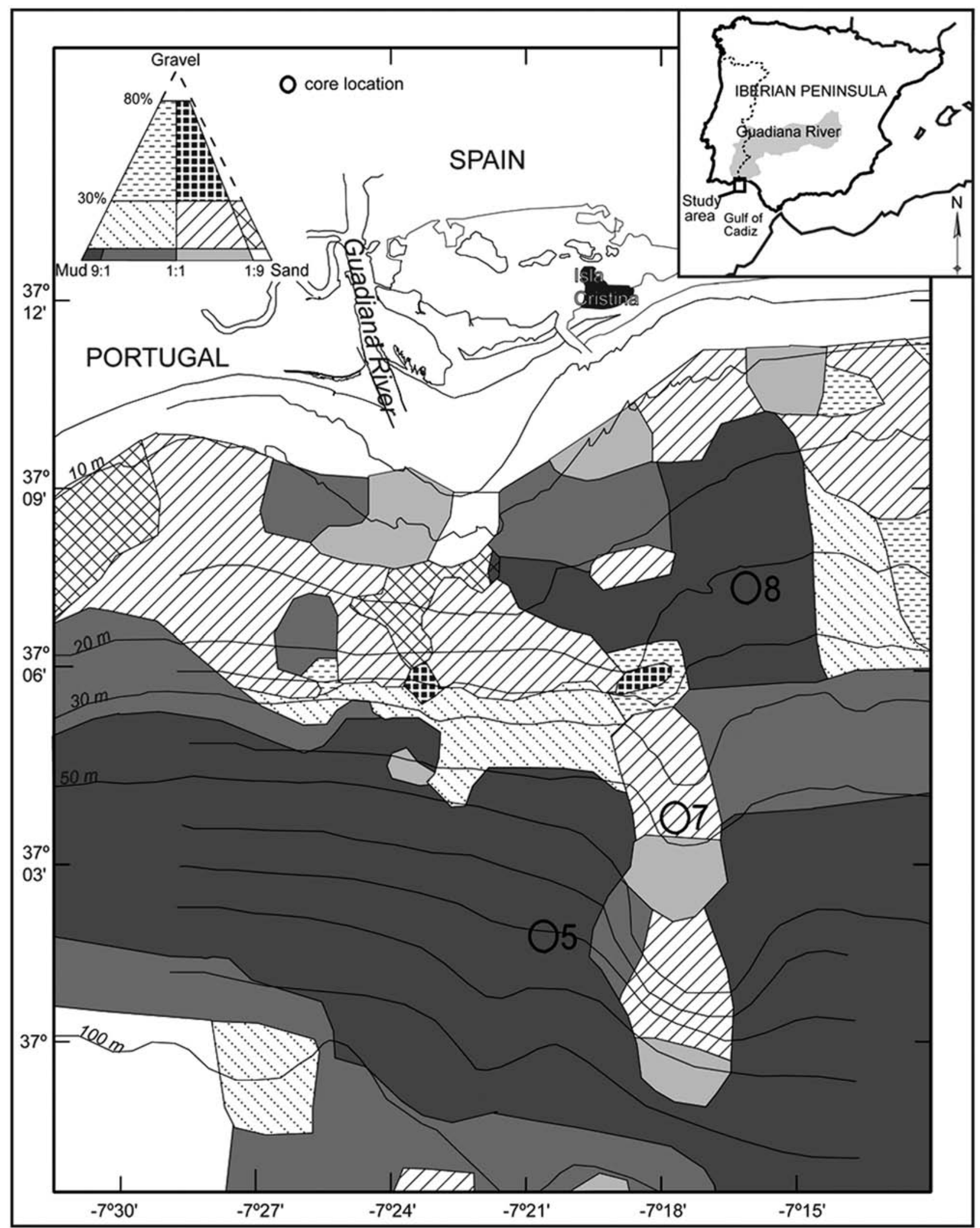

Figure I. Locations of the studied cores $(5,7$, and 8$)$ and distribution of surface sediments on the continental shelf off the Guadiana River (adapted from Gonzalez et al., 2004).

unweighted pair-group average (UPGMA). Q-mode cluster analyses grouped samples by using Ward's method.

Since ages are presented in the literature as either calibrated or uncalibrated dates, in order to compare them with our dates a conversion table from radiocarbon years (yr BP) to calendar ages (cal. yr BP) (and vice versa) was used according to Roberts (1998).

\section{Results}

Age models

The ${ }^{14} \mathrm{C}$ date of $c$. $11,500 \mathrm{cal}$. yr BP obtained at the base of core 5 indicated this core covers the largest time period (Table 1). Two periods of high sedimentation rate occurred, from $c$. 11,500 to $c$. 10,000 cal. yr BP and from c. 1000 cal. yr BP to Recent times. 
Table I. AMS radiocarbon data from cores 5, 7, and 8.AAR ages data from core 5 (Asp: aspartic acid; Glu: glutamic acid).

\begin{tabular}{|c|c|c|c|c|c|c|c|}
\hline \multirow[t]{2}{*}{ Core } & \multirow[t]{2}{*}{ Depth $(\mathrm{cm})$} & \multirow[t]{2}{*}{ Lab. no. } & \multicolumn{4}{|l|}{${ }^{14} \mathrm{C}$ dating } & \multirow{2}{*}{$\begin{array}{l}\text { AAR dating } \\
\text { Cal. age BP } \\
\text { (Asp-Glu) }\end{array}$} \\
\hline & & & $\begin{array}{l}\text { Conventional } \\
\text { radiocarbon age BP }\end{array}$ & $\begin{array}{l}\text { Local reservoir } \\
\text { effect }\end{array}$ & $\begin{array}{l}2 \sigma \text { calibrated age } \\
\text { BC/AD. }\end{array}$ & Cal. age BP & \\
\hline 5 & $40-41$ & UAL-678I & - & - & - & - & $366-486$ \\
\hline 5 & $94-96$ & UAL-6782 & - & - & - & - & $719-1061$ \\
\hline 5 & $102-104$ & Beta-211322 & $1650 \pm 40$ & $-135 \pm 20$ & AD 5I3-705 & $1245-1437$ & - \\
\hline 5 & $150-152$ & Beta-204306 & $4170 \pm 40$ & $100 \pm 100$ & $2456-1877$ BC & $3827-4406$ & - \\
\hline 5 & $206-208$ & Beta-2II324 & $9320 \pm 50$ & $0 \pm 100$ & 8494-7846 BC & $9796-10,444$ & - \\
\hline 5 & $350-352$ & Beta-194504 & $10400 \pm 70$ & $0 \pm 100$ & 9987-9233 BC & $11,183-11,937$ & - \\
\hline 7 & 4-8 & Beta-248644 & $1540 \pm 40$ & $-135 \pm 20$ & AD $632-820$ & $1130-1318$ & - \\
\hline 7 & $35-37$ & Beta-2II325 & $6480 \pm 40$ & $0 \pm 100$ & $528 \mathrm{I}-4775 \mathrm{BC}$ & $6725-7231$ & - \\
\hline 7 & $62-64$ & Beta-248643 & $8920 \pm 40$ & $0 \pm 100$ & $7998-7424$ BC & $9373-9947$ & - \\
\hline 8 & $76-78$ & Beta-204308 & $1120 \pm 40$ & $-135 \pm 20$ & AD $1048-1252$ & $698-902$ & - \\
\hline 8 & $156-158$ & Beta-204309 & $1750 \pm 40$ & $-135 \pm 20$ & AD $4|7-63|$ & $1319-1533$ & - \\
\hline 8 & $300-302$ & Beta-204310 & $3800 \pm 40$ & $0 \pm 100$ & $2091-1518$ BC & $3468-404 \mid$ & - \\
\hline 8 & $374-376$ & Beta-194506 & $4870 \pm 40$ & $0 \pm 100$ & $3487-2920 \mathrm{BC}$ & $4870-5437$ & - \\
\hline
\end{tabular}

A lower (by a factor of 10) sedimentation rate prevailed between c. 10,000 and c. 4000 cal. yr BP (Figure 2a). Core 7 presented the lowest sedimentation rates. The age data indicated decreasing sedimentation rates upward through the core (Figure $2 b$ ). Core 8 covers only the depositional period from c. 5150 cal. yr BP onwards (Table 1) and exhibited the highest sedimentation rates (Figure 2c). The deposits of cores 7 and 8 indicate a relatively continuous sediment input.

\section{Sedimentology}

In core $5,61-100 \%$ of the sediment was made up of fines (silt+clay) (Figure 3a; Appendix 1, available online). The silt fraction was the most abundant, and the coarse fraction was essentially constituted by sand. The maximum value for sand was observed near the core base. A decrease in the sand fraction during the last 4000 cal. yr BP coincided with an increase in the clay fraction. The mean grain size showed a fining-upward trend varying from 5.13 to 8.34 phi (Figure 3a).

Core 7 was constituted mainly by coarse sediments and sand was the most abundant fraction (54-95\%) (Figure 3b; Appendix 1, available online). Two periods of an increased proportion of fine fraction were observed, between c. 8000 and 6000 cal. yr BP and from c. $2500 \mathrm{cal}$. yr BP until Recent times. The mean grain size varied from 1.24 phi (at c. 2500 cal. yr BP) to 4.36 phi (top of the core) (Figure 3b).

In core 8 , grain size analyses allowed the identification of two distinct units along the core (Figure 3c; Appendix 1, available
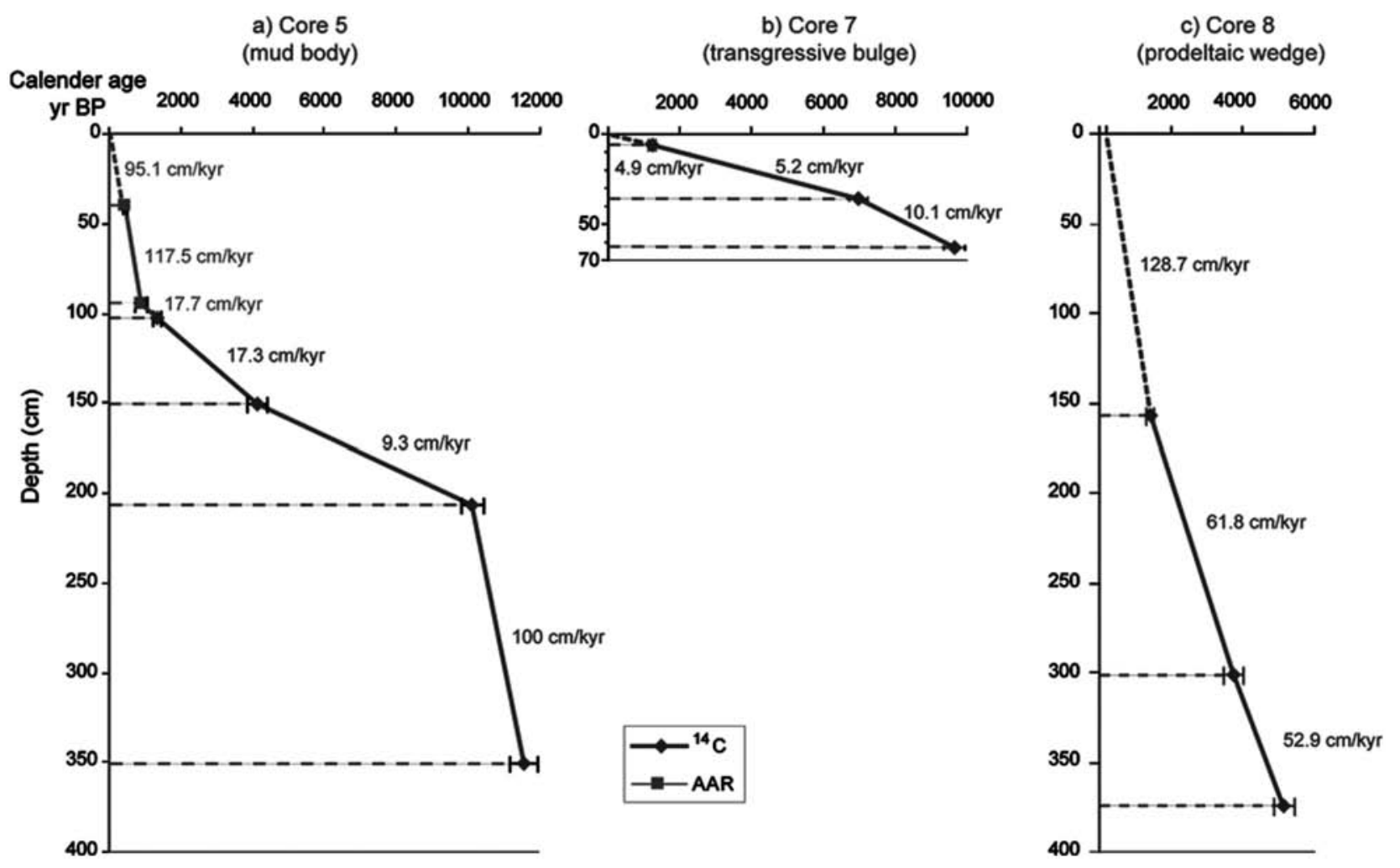

Figure 2. Age model for cores 5, 7, and 8, based on calibrated ages with confidence bars of age variation, and sedimentation rates between age control points. 


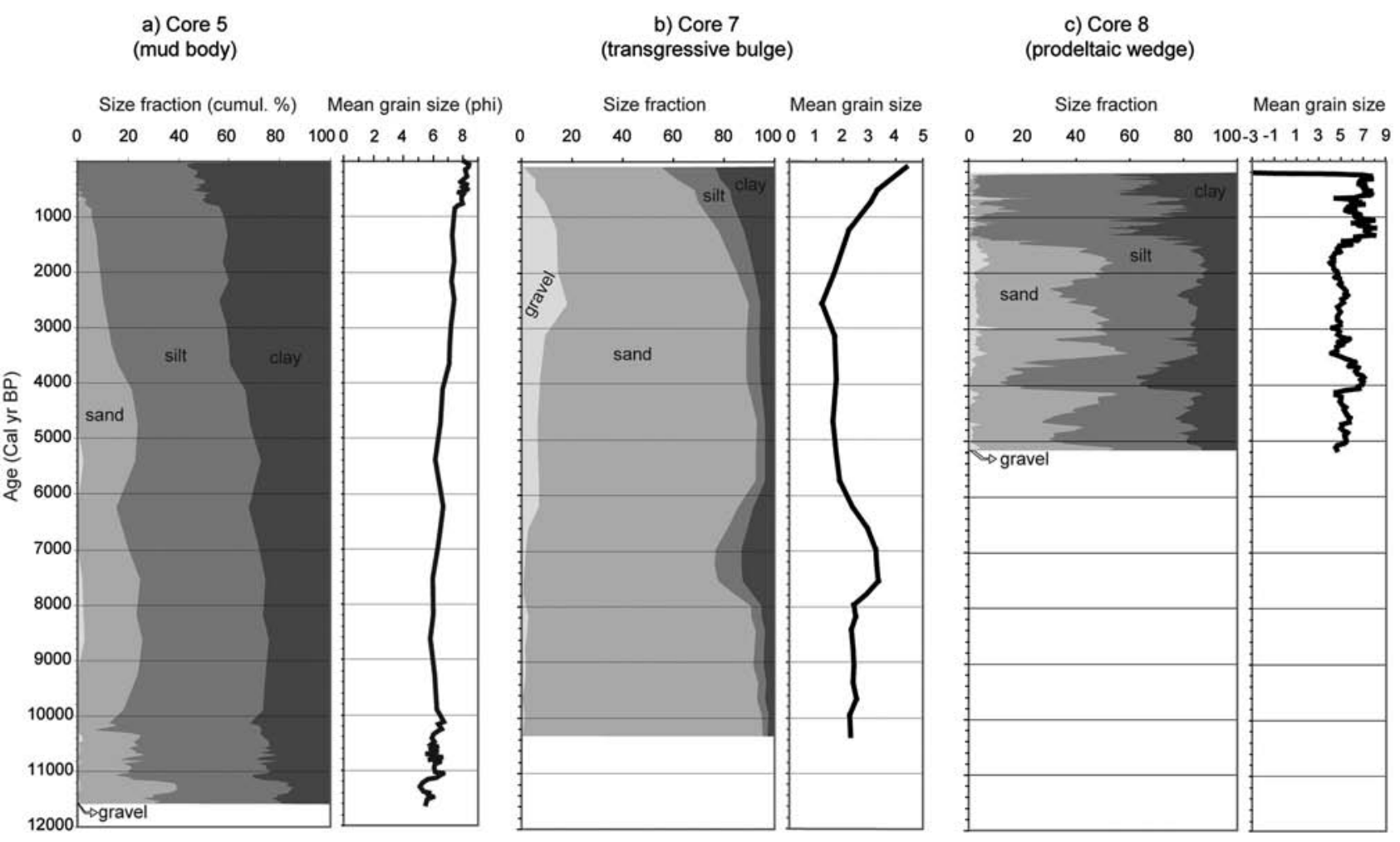

Figure 3. Size fraction and mean grain size variations with age (cal.yr BP) for the three environments analysed on the Guadiana continental shelf.

online). The lower unit, from c. 5150 to $c .1500-1400$ cal. yr BP, presented similar percentages of fine and coarse fractions. The upper unit, from c. 1500-1400 cal. yr BP to the core top (c. 200 cal. yr BP), was characterized by a higher proportion of silt-clay, reaching more than $90 \%$ of total sediments. Along core 8 , the mean grain size varied between -2.72 phi at the top of the core and 8 phi at c. 1200 cal. yr BP (Figure 3c).

Sand fraction analyses (Appendix 1, available online) showed that terrigenous components dominate core 5 from $c$. 11,500 to $c$. $400 \mathrm{cal}$. yr BP, while bioclasts (foraminifera and other bioclastic grains) prevail in the younger part of the core (Figure 4a). Within the succession dominated by terrigenous components, two distinct units were identified. The lower unit, extending from the core base to $c$. 5000 cal. yr BP, is dominated by quartz (56-88\%), mica $(0.7-23 \%)$ and other terrigenous $(0.4-12 \%)$. During this period, glauconite reached values of $3 \%$. The second unit, extending from around c. 5000 to $c .400 \mathrm{cal}$. yr BP, showed a decrease in both mica and other terrigenous, and increases in glauconite (3$16 \%$ ), foraminifera (6-21\%), and other bioclasts $(0.4-13 \%)$.

In core 7, quartz was the principal component (71-90\%). Between c. 8500 cal. yr BP and c. 1200 cal. yr BP, bioclastics increased to a maximum of $24 \%$ (Figure $4 \mathrm{~b}$ ).

In core 8, quartz (46-75\%) was the main component, but other terrigenous and mica also showed relatively high percentages (Figure 4c). Two distinct units could be identified. The lower unit, from $c$. 5150 to $c .1500-1400$ cal. yr BP, presented relatively constant percentages of all sand fraction components. The upper unit, from c. 1650-1400 cal. yr BP to c. 200 cal. yr BP, showed an increase in the terrigenous components reaching a maximum of 95\%. The transition between the units occurred at c. 1500-1400 cal. yr BP, when the silt-clay fraction shows a marked increase (Figure 3c).

\section{Benthic foraminifera}

Density and species richness. The highest values of foraminiferal population density (number of benthic foraminifera per gram of dry sediment) were obtained in core 5 ( $755-4543$ specimens $/ g)$ and the lowest in core 7 (16-320 specimens/g) (Figure 5a). In core 8 , the population density (17-3090 specimens/g) generally decreased from the base to the core top (Figure 5a).

The lower and more stable values of species richness were observed in core 5 (46-74 species). In contrast, greater variations and values were observed in core 7 (45-96 species) and the greatest in core 8 (30-115 species) (Figure $5 b)$. These results indicate that greater numbers of specimens are not related to greater numbers of species.

The Shannon diversity index remained relatively constant through all three studied cores. In core 5, it ranged from 2.6 to 3.3 , in core 7 from 3.17 to 3.84 , and in core 8 from 3.11 to 4.05 (Figure 5 c).

Cluster distribution. Cluster analyses were performed using the species that showed an abundance $>5 \%$. In core 5 , these species comprised between 68 and $82 \%$ of all species found in the analysed samples. In core 7 they comprised between 40 and $56 \%$ and in core 8 between 44 and $63 \%$ of all species found in the samples.

R-mode cluster analyses performed on the foraminiferal species data from each core produced three dendrograms and each one discriminated two clusters: cluster I and cluster II (Figure $6 a-c)$. Main species from each cluster are discriminated below. Q-mode cluster analyses also produced three dendrograms and each one distinguished two clusters: cluster A and cluster B (Figure 6d-f). Cluster A grouped all samples with older ages (except one): core 5 from $c .11,560$ to $c .4959$ cal. yr BP (Figure 6a); core 7 from $c .10,400$ to $5400 \mathrm{cal}$. yr BP (Figure 6b) and core 8 from $c$. 5000 to $c .1360$ cal. yr BP (Figure 6c). Cluster B grouped all samples (except one) with younger ages: core 5 from c. 4117 cal. yr $\mathrm{BP}$ to Recent times (Figure 6d); core 7 from c. 5400 cal. yr BP to Recent times (Figure 6e) and core 8 from c. 1300 to $c .200$ cal. yr BP (top core) (Figure 6f). The exceptions occurred in core 7 when a sample collected at the core base, $c$. 10,400 cal. yr BP, was included in cluster B, and the sample collected at c. 4090 cal. yr $\mathrm{BP}$ was included in cluster A (Figure 6b, e). 
a) Core 5 (mud body)

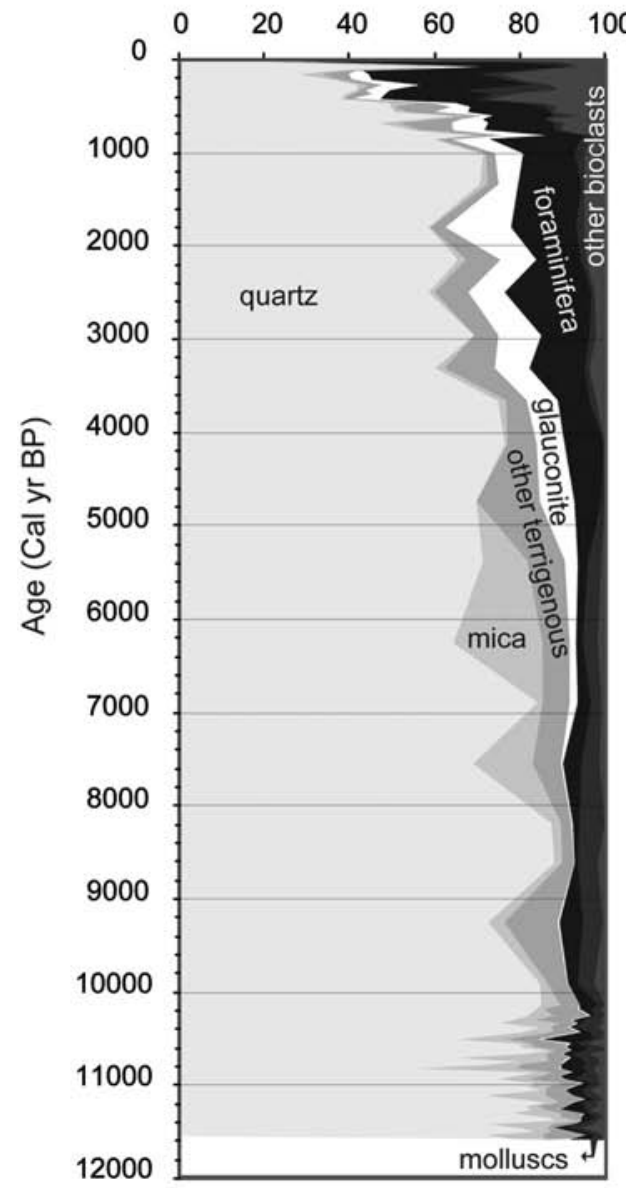

b) Core 7

(transgressive bulge)

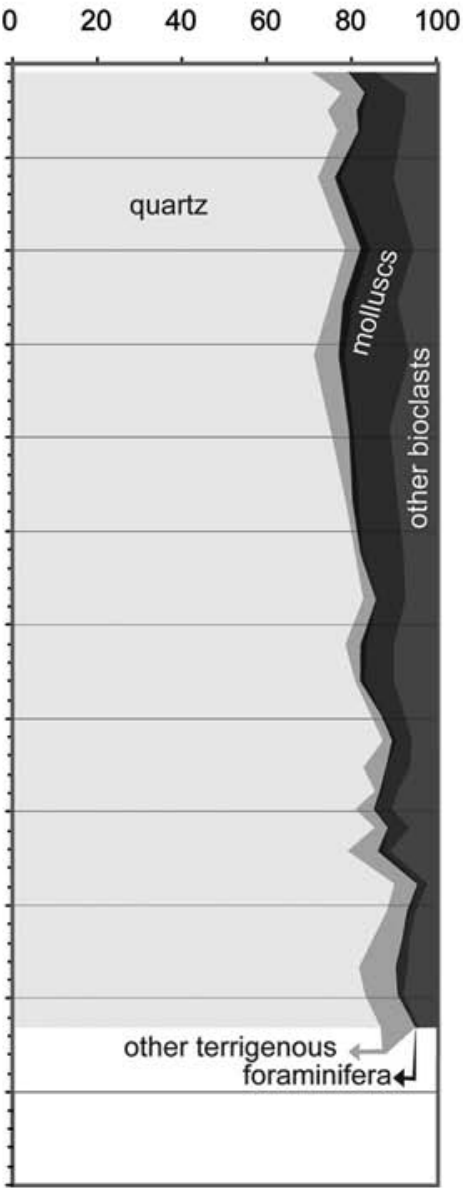

c) Core 8

(prodeltaic wedge)

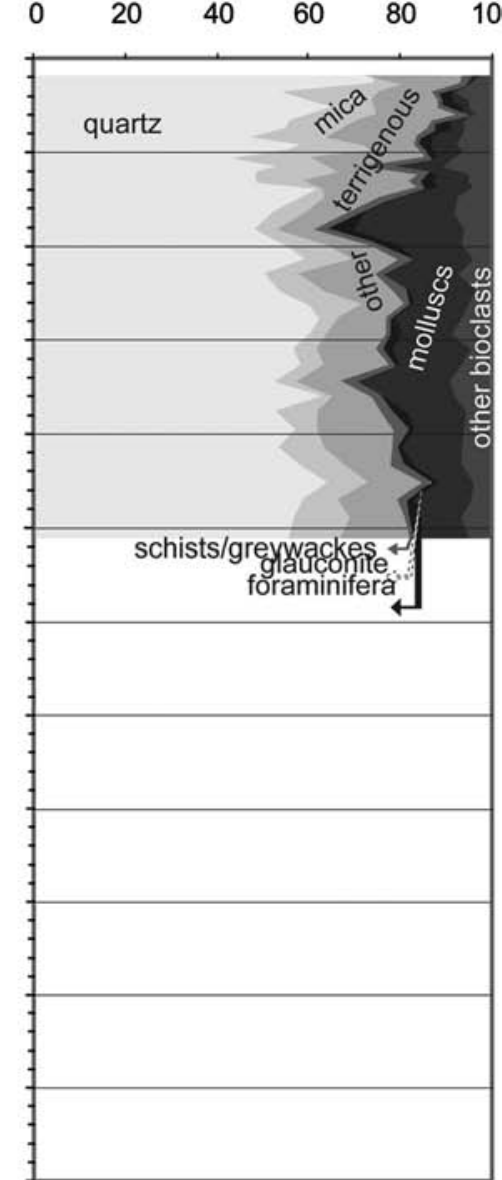

Figure 4. Variation in the components of the sand fraction with age (cal.yr BP) for the three environments analysed on the Guadiana continental shelf.

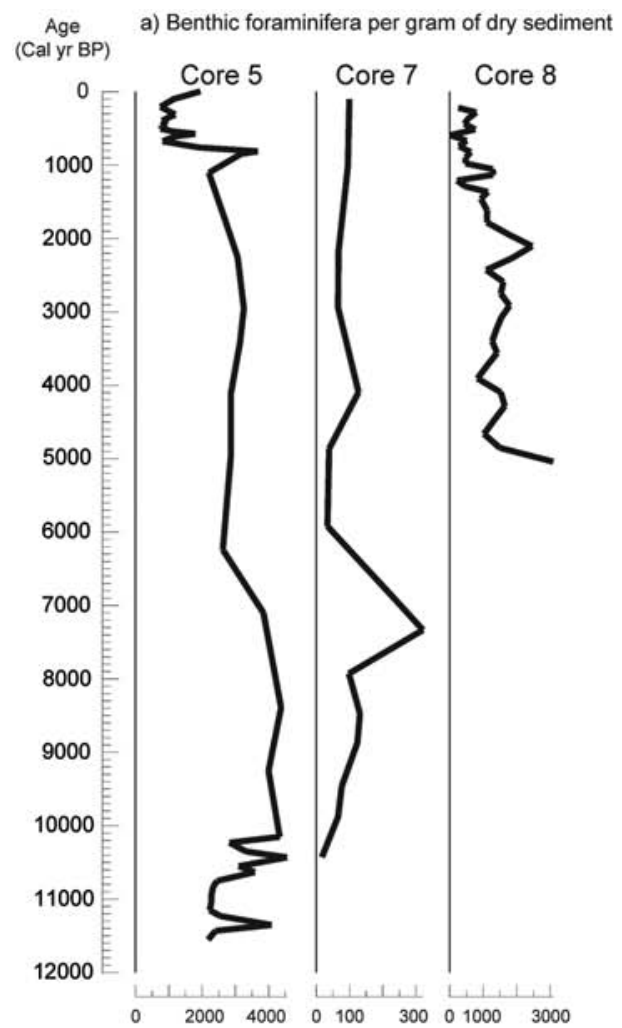

b) Species richness

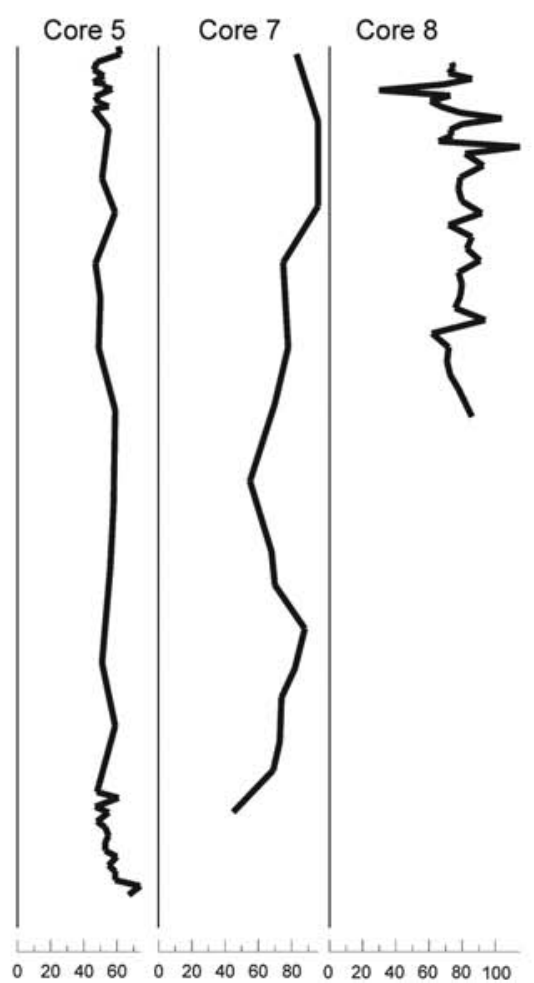

c) Shannon Index $(\mathrm{H})$

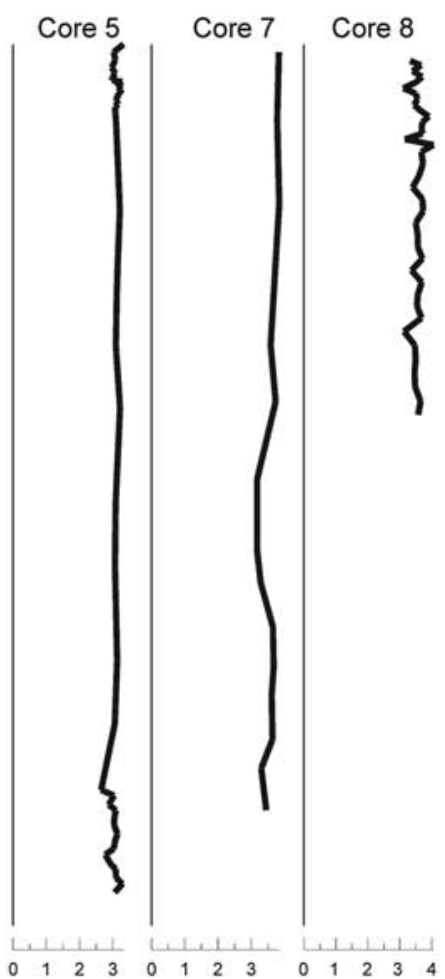

Figure 5. Variation with age (cal.yr BP) in: (a) benthic foraminifera per gram of dry sediment; (b) species richness; (c)Shannon Index, for the three environments analysed on the Guadiana continental shelf. 


\section{R-mode}

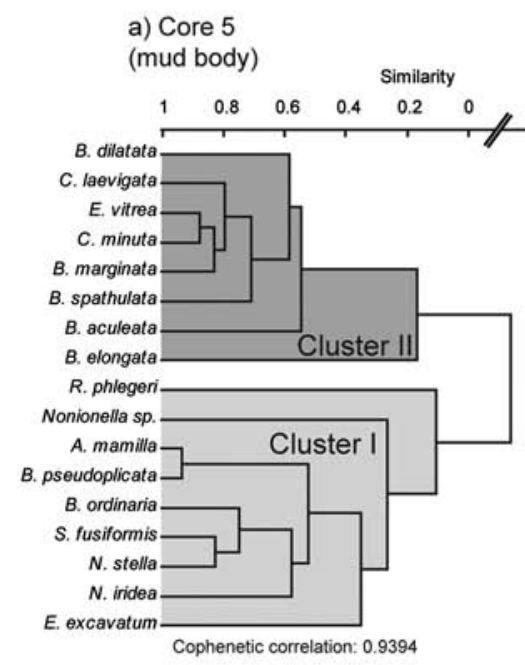

\section{Q-mode}

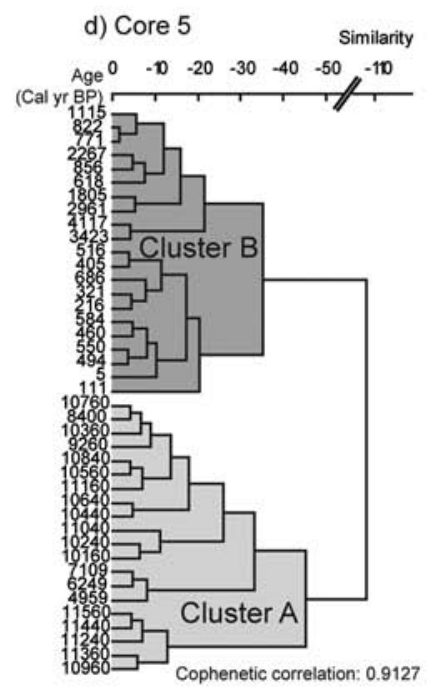

b) Core 7

(transgressive bulge)
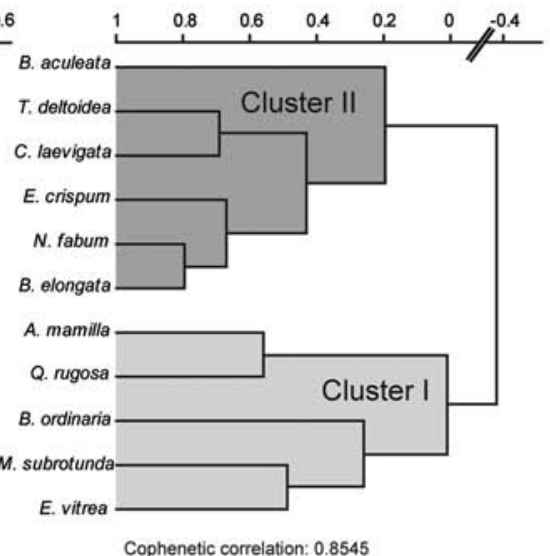

Cophenetic correlation: 0.8545 c) Core 8

(prodeltaic wedge)

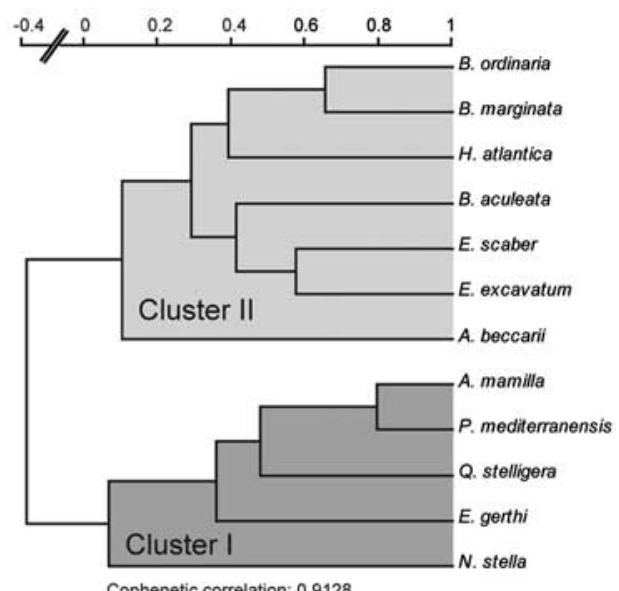

f) Core 8

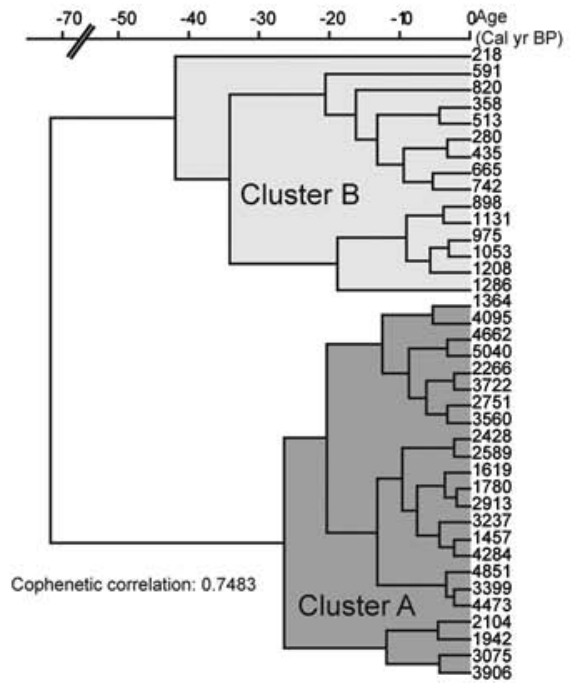

Figure 6. Dendrogram classification resulting from cluster analyses based on species with relative abundance $>5 \%$ in at least one sample, in cores 5, 7, and 8: (a), (b) and (c) Foraminiferal assemblages produced by R-mode analysis (correlation method joined by UPGMA); (d), (e) and (f) samples associated produced by Q-mode analysis (Ward's method).

Individual species distribution. Along core 5, the individual distributions of 17 species with abundance $>5 \%$ showed two general trends (Figure 7a; Appendix 2, available online). The first trend was characterized by a high abundance or gradual decrease from $c$. $11,500 \mathrm{cal}$. yr BP to $c .4500 \mathrm{cal}$. yr BP, with a further decrease in abundance from this level to the top of the core, with abundances $<1 \%$ or even a complete disappearance of certain species (Figure 7a). Typical examples of these species were Asterigerinata mamilla (Williamson) (0-22.8\%), Bolivina ordinaria Pheleger and Parker (3.8-36.5\%), Bolivina pseudoplicata Heron-Allen and Earland (0-5.4\%), Elphidium excavatum (Terquem) (0.2-9.3\%), Nonionella sp. (0.3-5.4\%), Nonionella iridea Heron-Allen and Earland (0.5-6\%), Nonionella stella Cushman and Moyer (0$11 \%)$, Rectuvigerina phlegeri Le Calvez (0.9-7\%), and Stainforthia fusiformis (Williamson) (0-10.9\%). The second trend was characterized by lower abundances from the core base to $c .4500$ cal. yr BP and an increase from this level to the top of the core. Typical examples of these species were Brizalina dilatata (Reuss) (0.3-10.7\%), Brizalina spathulata (Williamson) (0-17.2\%), Bulimina aculeata d'Orbigny (0.3-9.6\%), Bulimina elongata d'Orbigny (0-5.2\%), Bulimina marginata d'Orbigny (0-6.1\%), Cassidulina laevigata d'Orbigny (0-21.9\%), Cassidulina minuta
Cushman (0-5.3\%), and Epistominella vitrea Parker (0.9-17.3\%). An exception to this pattern was C. laevigata, which showed an earlier increase in abundance, at c. $7000 \mathrm{cal}$. yr BP (Figure 7a). The individual distributions shown by these species are closely linked with R-mode cluster analyses obtained for core 5 (Figure 6a): species described in the first trend correspond to cluster I, while species from the second trend form cluster II (Figure 7a). The zonation method produced two zones along core 5, the older zone stretching from $c$. 11,500 to c. $4500 \mathrm{cal}$. yr BP, and the younger zone from 4500 cal. yr BP to Recent times (Figure 7a).

Ten species were most abundant along core 7 (Appendix 2, available online). Again, two general trends could be identified (Figure $7 \mathrm{~b}$ ). The first trend was characterized by species with high or decreasing abundances between c. 10,400 and c. 5400 cal. yr BP: Asterigerinata mamilla (0-6.3\%), Bolivina ordinaria (8.9-32.8\%), Epistominella vitrea (1.9-7.9\%), Miliolinella subrotunda (Montagu) (0.9-6.1\%), and Quinqueloculina rugosa d'Orbigny (0$13.3 \%$ ). Of these species, only $Q$. rugosa showed higher abundance at the core base, however, dropped abruptly to values $<2 \%$ in the next analysed level. From c. 5400 cal. yr BP to the core top, the aforementioned species decreased in abundance. The second trend was characterized by species displaying increasing abundance from 
a) Core 5

(mud body) b) Core 7

(transgressive bulge) c) Core 8

(prodeltaic wedge)
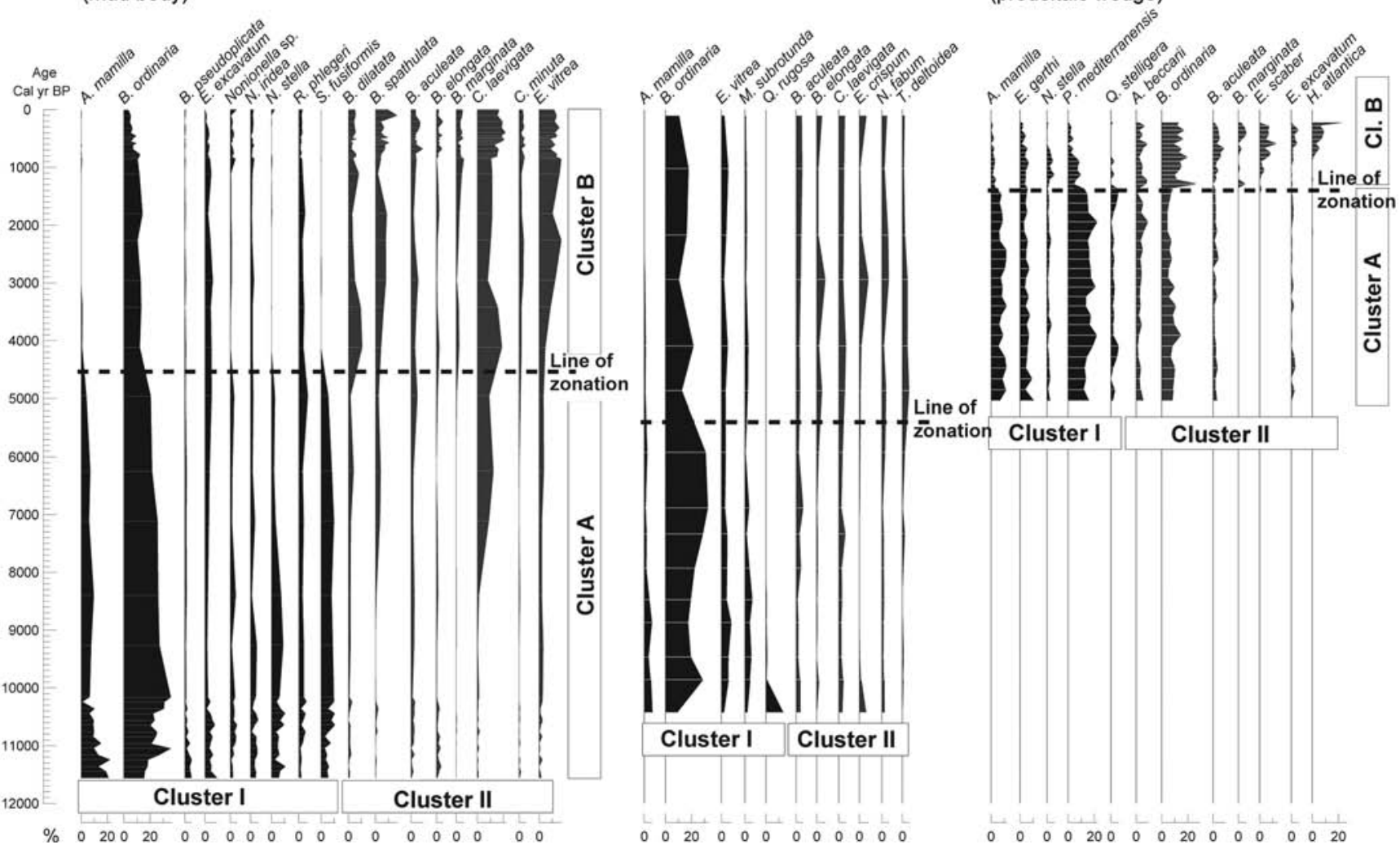

Figure 7. Variation with age (cal. yr BP) of the relative abundances of benthic foraminiferal species, with abundance $>5 \%$ in at least one sample, for the three environments analysed on the Guadiana continental shelf. The results obtained by R-mode (Cluster I and II) and by Q-mode (Cluster A and B) cluster analyses, when consistent, are also represented. The dashed lines indicate the results obtained by the zonation method in each environment.

c. 5400 cal. yr BP to the top: Bulimina aculeata (1.2-5.6\%), Bulimina elongata (0-6.9\%), Cassidulina laevigata (2.2-5.7\%), Elphidium crispum (Linnaeus) (0-7.3\%), Nonion fabum (Fichtel and Moll) (0.8-5.6\%), and Textularia deltoidea Reuss (0-5.5\%). The distribution trends shown by these species can be closely related to the clusters obtained for core 7 (Figure 6b). The first trend corresponds to cluster I, while the second corresponds to cluster II (Figure $7 \mathrm{~b}$ ). The zonation method produced two zones in core 7 , the first zone from $c .10,400$ to $c .5400 \mathrm{cal}$. $\mathrm{yr} \mathrm{BP}$, and the second zone from 5400 cal. yr BP to Recent times (Figure 7b).

Along core 8,12 benthic foraminiferal species showed relative abundances $>5 \%$ (Appendix 2, available online). As in the other cores, two trends could be observed (Figure 7c). The first trend was characterized by relatively high and constant abundances from the core base to $c$. 1400-1200 cal. yr BP, followed by a decrease. Typical species were: Asterigerinata mamilla (0-12\%), Elphidium gerthi Van Voorthuysen (1-10\%), Nonionella stella (0-6\%), Planorbulina mediterranensis d'Orbigny (0-23\%), and Quinqueloculina stelligera Schlumberger (0-6\%). The second trend was characterized by species with low abundance from the core base to $c .1400 \mathrm{cal}$. yr BP, and increased abundance from this level to the core top (c. 200 cal. yr BP) (Figure 7c). Examples included Ammonia beccarii (2-10\%), Bolivina ordinaria (5-29\%) (with different trend than previous cores), Bulimina aculeata (0-9\%), Bulimina marginata (0-6\%), Eggerelloides scaber (Williamson) (0-14\%), Elphidium excavatum (0-6\%), and Hopkinsina atlantica (Cushman) (0-27\%). Eggerelloides scaber and A. beccarii presented peak abundances of 14 and $10 \%$, respectively, around c. 600 cal. yr BP. These groups of species are closely linked with R-mode cluster analyses obtained for core 8 (Figure 6c). Species from the first trend correspond to cluster I and species from the second trend to cluster II (Figure 7c). The zonation method produced two zones along core 8 . The first zone, from c. 5000 cal. yr BP (core base) to c. $1350 \mathrm{cal}$. yr BP, and the second zone from 1350 cal. yr BP to c. 200 cal. yr BP (core top) (Figure 7c).

\section{Discussion}

The environments on the continental shelf off the Guadiana River, as analysed above, differed in terms of depth (Figure 1), sedimentary regime (Figures 3,4 ), and constituent benthic foraminiferal assemblages (Figures 5, 7). They are regarded as typical marine shelf environments, owing to the relatively constant values of the Shannon index diversity (Murray, 2006) (Figure 5c). A dominant fluvial origin of the sand fraction was inferred for the three analysed environments through the abundance of quartz and the significant amount of mica and other terrigenous components (Figure 4). Sediment remobilization was considered to play a minor role and not to bias the sedimentary record because the radiocarbon dates showed coherently increasing values with core depth (Table 1). Sedimentary structures indicating disturbances were not observed in sediment cores when they were opened. Burdloff et al. (2008) found, however, in upper part of core 5 breaks in the decay profiles of ${ }^{210} \mathrm{~Pb}$ excess activity. These steps in the activity profiles were probably related to single events with a massive input of sediment. The results obtained allow the identification of four evolutionary stages, described in turn below. These stages provide information about sedimentary deposition through the Holocene in consequence of both natural and anthropogenic processes. 


\section{Sea level curve}

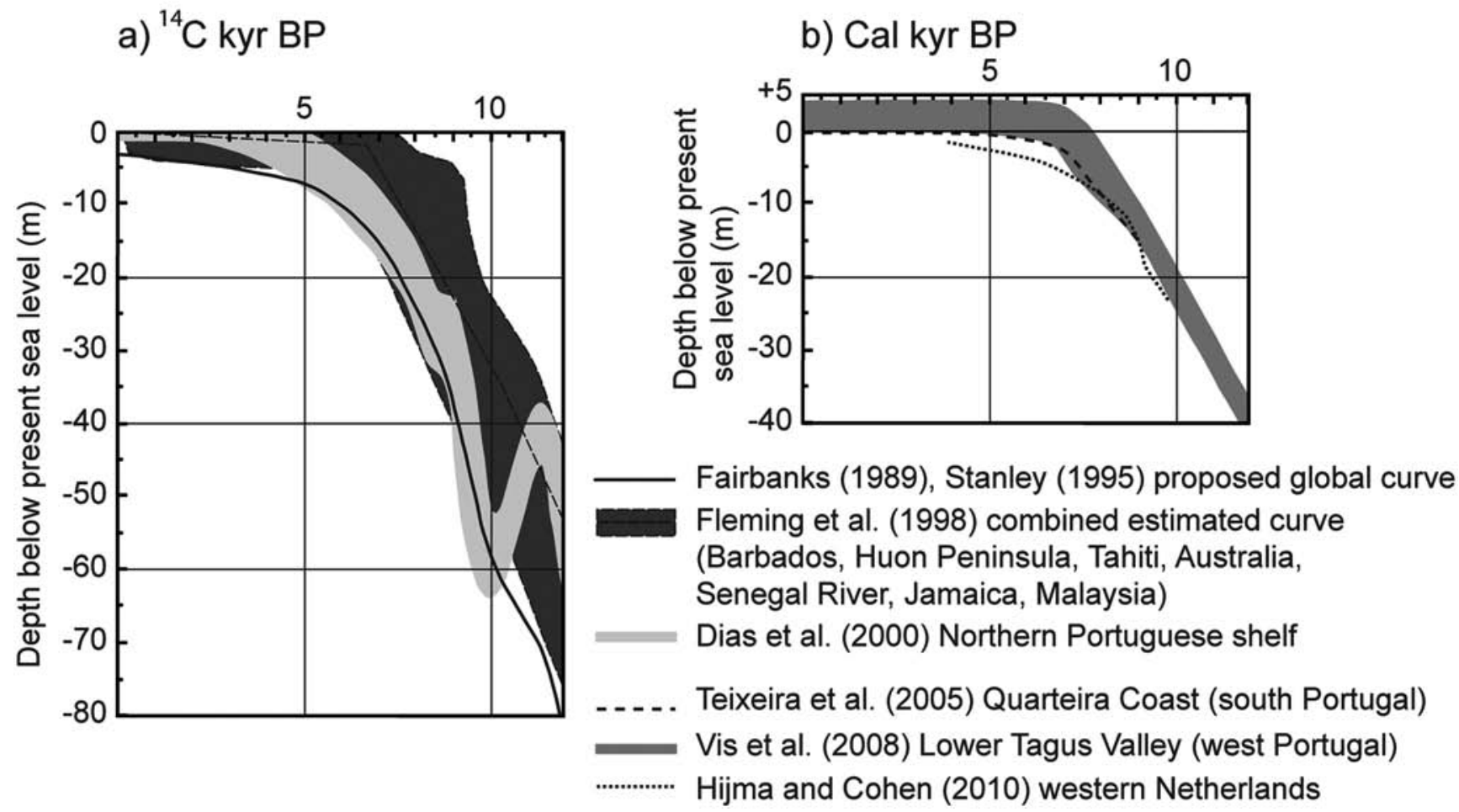

Figure 8. Sea level curves, proposed by different authors with respective locations. Variation in depth below present sea level with: (a) radiocarbon ages (kyr BP); (b) calibrated age (cal. kyr BP).

\section{From c. I I,500 to c. 10,000 cal. yr BP}

The beginning of the Holocene was characterized by a rapid rise in sea level until c. 7000-5700 cal. yr BP, at which time the rate of rise decreased substantially (e.g. Dias et al., 2000; Fairbanks, 1989; Fleming et al., 1998; Hijma and Cohen, 2010; Stanley, 1995; Teixeira et al., 2005; Vis et al., 2008) (Figure 8). The global sea level curve proposed by Stanley (1995) and the sea level curve for the northern Portuguese shelf (Dias et al., 2000) indicate a variation of 15 to $25 \mathrm{~m}$ in water depth during the period from $c$. 11,500 to $c .10,000$ cal. yr BP (c. 10,000 to $c .9040 \mathrm{yr}$ BP) (Figure $8 \mathrm{a})$. At the beginning of this period, mean sea levels were approximately $55-60 \mathrm{~m}$ below present and $35-40 \mathrm{~m}$ below present at $c$. 10,000 cal. yr BP (Figure 8a). In contrast, the relative sea level curve for the Lower Tagus Valley (west Portugal) indicates sea levels $40 \mathrm{~m}$ and $22 \mathrm{~m}$ below present at c. 11,500 and c. 10,000 cal. yr BP, respectively (Vis et al., 2008) (Figure 8b).

At present, fine-grained sediments occur on the shelf study area between 35 and $100 \mathrm{~m}$ water depth (Gonzalez et al., 2004). If similar conditions existed in the beginning of the Holocene, the base of core 5 would have been located in an area corresponding to the shallowest limit of fine-grained sedimentation. Core 7 would probably have been located in the vicinity of the paleomouth of the Guadiana River in a shallow marine environment. Thus it indicates that the obtained results seem to be more in accordance with the proposed sea level curve of Vis et al. (2008) and Teixeira et al. (2005), in which the mean sea level would have been closer to the present one (Figure 8b).

During this period, high sedimentation rates of sandy mud were recorded in core 5 , in agreement with the observations of Nelson et al. (1999) of $131 \mathrm{~cm} / \mathrm{ka}$ in a core located southeast of the Guadiana River mouth at mid-shelf water depths. For the middle shelf mud body (core 5), this period was characterized by the highest percentages of sand (Figure $3 \mathrm{a}$ ) and by the highest sedimentation rates, resulting in an accumulation of about $1.5 \mathrm{~m}$ of sediment (Figure 2a). An increasing abundance of $B$. ordinaria, normally associated with a high organic matter content (Martins et al., 2006), can be observed (Figure 7a). This is very likely associated with higher influence of the discharges from the Guadiana River at this time. Simultaneously, A. mamilla shows a decrease in abundance (Figure 7a), indicating a deepening sedimentary environment and a reduction in hydrodynamic energy levels near the bottom. This is in accordance with Mendes et al. (2004) who described high abundances of this species on the inner shelf off the Guadiana River in waters shallow than $12 \mathrm{~m}$, and associated with a mixture of mud and sands.

In the upper middle shelf transgressive bulge (core 7), only the period between $c .10,400$ and c. 10,000 cal. yr BP is represented. It was characterized by the lowest benthic foraminiferal population density (Figure 5a), and the lowest abundance of $B$. ordinaria. Simultaneously, the greatest abundance of Q. rugosa observed through the core (Figure 7b) is in agreement with Villanueva et al. (1999), which described Quinqueloculina rugosa (as Cycloforina rugosa) associated with sands and high organic matter content. Indicating a sandy environment rich organic matter and dominated by $Q$. rugosa.

\section{From c. 10,000 to c. 5000 cal. yr BP}

This period was characterized by a rapid and continuous rise in sea level until c. 7000-5700 cal. yr BP, after which the rate of the rise decreased significantly (Figure 8 ). The fast sea level rise led to an accelerated phase of infilling of the Guadiana Estuary (Boski et al., 2002). This infilling began mainly with clay deposition in the period between 9800 and $6500 \mathrm{yr} \mathrm{BP}(c .10,700$ to $c$. 7380 cal. yr BP), followed by coarser sediments in the central part of the estuary, between 7500 and $7000 \mathrm{yr}$ BP (c. 8220 to c. 7787 cal. yr BP) (Boski et al., 2002). In the study area, the period of estuary infilling resulted in a reduction of sediment exported to 
the adjacent shelf. The consequent decrease in sedimentation coincides with the lowest sedimentation rates observed in core 5 on the middle shelf mud body (Figure 2a). Furthermore, the progressive decrease in mean grain size (Figure 3a) indicates that fine-grained sediments were exported mainly to the shelf while most coarse-grained sediments were retained inside the estuary. This is in accordance with Lantzsch et al. (2009), which observed a transition from fine sands towards mud on the central Muros and Galicia mud belts (NW Iberia), during this period. The analysed sediments were interpreted to reflect a deepening environment which resulted in low hydrodynamic levels, and the decrease influence of Guadiana River discharges. This was confirmed by the high abundances of opportunistic and/or highly adapted benthic foraminiferal species observed during this period (Figure 7a). The most abundant species found coexisting in this part of the core 5 have different ecological requirements. Some of the species characterizing this period are highly adapted to a specific environment, such as A. mamilla, described in shallow waters and associated with a mixture of mud and sand or sandy sediments (e.g. Jorissen, 1987; Mendes et al., 2004; Samir and El-Din, 2001). Other species are opportunistic and have been associated with high organic matter contents, such as $B$. ordinaria (Martins et al., 2006) and E. excavatum (de Nooijer et al., 2008). Rectuvigerina phlegeri is also influenced by river discharges (Mojtahid et al., 2009) and described on muddy bottoms characterized by high organic matter contents (Frezza and Carboni, 2009; Villanueva and Cervera, 1999a). Species such as S. fusiformis, considered to have an opportunistic life-strategy and to be highly adapted to environmental stress, predominate in areas subject to rapidly changing environmental conditions (Alve, 2003). This period, therefore, could be interpreted as an environment in a state of disequilibrium under the influence of multiple changing parameters, reflecting shifts in water depth, sediment supply, and hydrodynamic levels.

On the upper middle shelf transgressive bulge (core 7), the impact of the Guadiana Estuary infilling seems to show a visible influence only in the period between $c .7500$ and c. 7000 cal. yr BP. During this period, while sands remained the dominant textural class, an increase in fines was observed (Figure 3b), probably as a consequence of the retention of most of the coarser sediments inside the estuary (Boski et al., 2002). The temporal discrepancy between the estuary infilling reported by Boski et al. (2002) and the sedimentary changes observed for this area of the shelf could indicate a time lag for the final deposition of finegrained sediments after successive periods of deposition and remobilization.

The 4 to $5 \mathrm{~km}$ wide and $4 \mathrm{~km}$ long transgressive bulge on the continental shelf, where core 7 was collected, is elevated by $10 \mathrm{~m}$ in relation to adjacent areas and is composed of muddy gravelly sands and muddy sands (Gonzalez et al., 2004). The development of the bulge continues to be a topic of scientific discussion. Lobo et al. (2001) attribute its formation to a combination of reduced rates of sea level rise and increased sediment yields to the shelf, probably associated with the cold event centred around $8.2 \mathrm{kyr}$ BP. Gonzalez et al. (2004) interpret this body as a result of a period of rapid sediment accumulation related to floods in the Guadiana River basin, probably associated with a transition from a dry, cold period to a warmer, more humid, period. In the lower Guadiana valley, palynological evidence points to a short-lived event associated with arid conditions of wider regional significance around c. 8000 cal. yr BP (Fletcher et al., 2007). However, in the study area, the period from $c .10,000$ to $5000 \mathrm{cal}$. yr BP was characterized by relatively constant sedimentation rates (Figure $2 b$ ), small variations in grain size (Figure 3b), a sand fraction dominated by terrigenous components (Figure 4b), and a low benthic foraminiferal population density (Figure 5a), together indicating that the $8.2 \mathrm{kyr}$ event was not clearly recorded or that the event was not captured because of the comparatively low temporal resolution of the sample intervals in this part of the core.

As observed on the middle shelf mud body (core 5), the more abundant species on the transgressive bulge (core 7) have been reported in the literature as being highly adapted or opportunistic. Asterigerinata mamilla and B. ordinaria presented a similar trend as in core 5. In contrast, $E$. vitrea displayed opposing behaviour, being more abundant during this period in sandy sediments (Figure 7b), indicating opportunism. This species has been described on the middle shelf, where river discharge was enhanced (Duchemin et al., 2007), and in muddy sediments associated with low hydrodynamic levels (Mendes et al., 2004). Miliolinella subrotunda, which is more abundant only in this environment, decreased in abundance during this period, pointing to environmental changes. This species has been described in sediments having more than $75 \%$ of sand (Levy et al., 1995). The high abundances of these species associated with sand could indicate a shallower environment strongly influenced by the bedload discharges from the Guadiana River. The low population density in core 7 (Figure 5a) and the high percentage of terrigenous components (Figure $4 b$ ) indicates that this area of the continental shelf was probably located in a shallower position, probably corresponding to a sedimentary environment similar to the present river mouth, where predominately terrigenous sands can be observed (Gonzalez et al., 2004).

\section{From c. 5000 to c. 1500-1000 cal. yr BP}

There is no worldwide or even regional consensus for the time at which the present-day sea level was reached. Most studies of sea level change indicate that it might have been reached at around 5700-5000 cal. yr BP (e.g. Dias et al., 2000; Fairbanks, 1989; Peltier and Fairbanks, 2006; Stanley, 1995; Zazo et al., 2008). In contrast, local studies in the Lower Tagus Valley (Vis et al., 2008) and on the Quarteira coast (Teixeira et al., 2005) indicate that present-day mean sea levels might have been reached as early as 7000 cal. yr BP (Figure 8b). However, there is general agreement that a rapid rise in sea level occurred until approximately c. 7000 cal. yr BP.

In this investigation, variations observed in components of the sand fraction (Figure 4) and benthic foraminiferal assemblages, also corroborated by statistical results obtained by cluster analysis and zonation methods (Figures 6 and 7), indicate that important changes occurred at around $5000 \mathrm{cal}$. yr BP. These changes clear identify the transition from low sea level to modern sea level. These results are in agreement with those obtained by Zazo et al. (2008) in southern Spain, and by Boski et al. (2002) in the Guadiana Estuary, where dates of c. 5700-5000 cal. yr BP were calculated for the attainment of present-day sea levels. Those authors documented, however, a phase of slower rise between 7000-6500 and $7380-5700$ cal. yr BP, respectively.

The results obtained for the three environments indicate relatively stable climatic and environmental conditions, after reaching the present mean sea level. On the middle shelf (core 5), the period reflects the depositional conditions that established the muddy body, after the stabilization of mean sea level. A decreasing trend of sand content and mean grain size (Figure 3a) could indicate the progressive disequilibrium of the estuary, with a progressive silting-up, until equilibrium with the new base level was reached (a hysteresis of estuarine sedimentation). This process led to a decrease in sedimentation rates of fine-grained sediments on the shelf (Figures 2a, 3a). These inferences are reinforced by an increase in glauconite sediments observed during this period (Figure 4a), normally associated with periods of little or no active sedimentation (e.g. Odin and Matter, 1981).

Faunal changes occurred at the beginning of this period, with a decreasing (increasing) abundance of species more adapted to 
shallow (deeper) environments. With the exception of B. elongata, the species that showed increased abundances during this period (Figure 5) were described at depths $>40 \mathrm{~m}$, associated with fine sediments and low hydrodynamic levels (Mendes et al., 2004). Furthermore, species such as B. spathulata, B. aculeata, and $B$. marginata have been reported in areas influenced by river discharges, in mud sediments characterized by high organic matter contents (e.g. Donnici and Barbero, 2002; Frezza and Carboni, 2009; Mojtahid et al., 2009). Cassidulina laevigata and B. marginata are also associated with fresh organic matter with high nutrition value (de Rijk et al., 2000). This indicates that the abundance of these species was affected not only by the establishment of a new, deep environment after reaching the present-day mean sea level, but also by an increasing contribution of organic matter that could be related to larger river discharges or to productivity changes. This interpretation is in accordance with that of Burdloff et al. (2008), who found (in core 5) an increasing contribution of finesized marine organic matter and an enhancement of terrestrial sediment supply during the upper Holocene.

The upper middle shelf transgressive bulge (core 7) is composed mainly of sands and is influenced by the Guadiana River discharges. Bolivina ordinaria remained the most abundant species (Figure 7b), and the most opportunistic of the assemblage, despite its decreased abundance. Six more species with different ecological requirements presented increased abundance during this period. These species have been described by Mendes et al. (2004) at various water depths and in different environments. For instance, E. crispum was described at depths $<12 \mathrm{~m}$ and C. laevigata at depths $>95 \mathrm{~m}$ and associated with different types of sediments (Mendes et al., 2004). The occurrence of these species with different ecological requirements indicates that the sandy substratum was the most important factor controlling their abundance or that mixing or transport could have occurred during this period.

The sedimentary sequence retrieved from the inner shelf prodeltaic wedge (core 8) reflects the environmental conditions achieved after the attainment of the present mean sea level. These sediments were interpreted as representative of a depositional unit formed under the direct influence of the Guadiana River. The description by Strabo (Geographica, III, 1, 9, Velozo and Cardoso, 1965) of the southern Iberian Peninsula reports the existence of two distributaries of the Guadiana Delta around 2000 cal. yr BP. This description, together with geomorphological evidence (e.g. Gonzalez et al., 2004), indicates that the easternmost distributary of the Guadiana estuary (probably in the present-day area of Isla Cristina) may have been responsible for direct river discharge into the location of the present-day prodeltaic wedge (Figure 1). This interpretation is supported by the similar percentages of the fine and coarse fractions (Figure 3c), by the relatively constant percentages of all components of the sand fraction (Figure 4c), and by the high abundances of A. mamilla, P. mediterranensis and $E$. gerthi (Figure 7c) which are characteristic of shallow and sandy environments (e.g. Mendes et al., 2004; Pujos, 1976; Villanueva and Cervera, 1999b).

\section{From c. I500-1000 cal. yr BP to Recent times}

Intensification of human impact on woodland resources and a considerable anthropogenic influence on the landscape occurred during the protohistoric periods (Iron age, Roman) in the Guadiana Valley (Fletcher et al., 2007). During the Roman occupation of the Iberian Peninsula, between $218 \mathrm{BC}$ and $\mathrm{AD} 411$ (c. 2168 to 1539 cal. yr BP), increased anthropogenic impact occurred in the Guadiana River, since it was used to transport agricultural products such as wine (Alarcão, 1988) and copper from the São Domingos mine (Fabião, 1992). Between 1500 and 1000 cal. yr $\mathrm{BP}$, the climate deteriorated in northern Europe, characterized by a rapid cooling, defined as the Dark Ages (Lamb, 1977). On the
Tagus prodelta, the period between $c$. AD 400 and 700 (c. 1550 to 1250 cal. yr BP - 'Dark Ages') could have been as warm as the 'Medieval Warm Period' (MWP) (Lebreiro et al., 2006). During the MWP, drier continental conditions and intensified coastal upwelling occurred on the Tagus prodelta (Abrantes et al., 2005; Lebreiro et al., 2006). On the Galician continental shelf relatively dry conditions were also observed between 1700 and 1200 cal. yr BP, however an increase precipitation over the NW Iberian Peninsula, with enhanced flow of the Minho and Douro rivers, occurred since c. 1200 cal. yr BP (Bernárdez et al., 2008). On the inner shelf prodeltaic wedge study area (core 8 ), the results obtained for the period between 1500 and $1200 \mathrm{cal}$. yr BP indicate that humid conditions occurred earlier, which combined with human activities allowed large volumes of sediment to be transported to the continental shelf, creating changes in the type of sediment and foraminiferal assemblages (Figures 3c, 7c). This interpretation is in agreement with Lesueur et al. (1996), which observed on the Gironde shelf an increasing deposition of fine-grained sediments and the formation of mud fields during the last c. $2000 \mathrm{yr}$ BP, linked to climatic fluctuations, combined with anthropogenic activities.

On the middle shelf mud body (core 5), a period of environmental transition occurred from c. 1000 to $c .800 \mathrm{cal}$. yr BP. It was characterized by a gradual increase of bioclastic components (Figure 4a), marked variations in benthic foraminiferal population density, and variations in benthic foraminiferal assemblages (Figures 5, 7). After this transition the period between $c .800$ cal. yr BP and Recent times was characterized by the new base level on the continental shelf, reflecting the recent depositional conditions. This equilibrium was indicated by the deposition of fine sediments and relatively constant mean grain size (Figure 3a), an increase in sedimentation rates (Figure 2a), and an increase in bioclastic components of the sand fraction (mainly foraminifera and other bioclasts) (Figure 4a). Furthermore, this interval coincides with the lower number of benthic foraminifera per gram of sediment (Figure 5a) and the relatively constant abundance of species characteristic of middle shelf environments.

On the upper middle shelf transgressive bulge (core 7), the last c. 1000 years were characterized by a relatively stable environment. The increase in the percentage of the fine fraction could be interpreted as recent fluvially derived sediments.

On the inner shelf prodeltaic wedge (core 8), a period of environmental transition was observed between c. 1500 and c. 1200 cal. yr BP. It was evidenced by a rapid increase in the fine fraction (Figure 3c), a smooth increase in the terrigenous component (Figure 4c), and important shifts in benthic foraminiferal assemblages, also confirmed by cluster analysis and zonation methods (Figures $6,7 \mathrm{c}$ ). The highest species richness occurred (Figure 5b), indicating that species from the lower and upper sedimentary units coexisted, until the establishment of the new environmental conditions. Furthermore, a greater abundance of $B$. ordinaria and B. marginata, normally associated with high amounts of organic carbon (Donnici and Barbero, 2002; Martins et al., 2006) also points to environmental changes (Figure 7c). After this transitional period and up to the core top, new climatic and environmental conditions were established. A more stable environment, with increased deposition of fines and greater availability of organic matter, is reflected by the higher abundance of $B$. ordinaria and $H$. atlantica (e.g. Diz and Francés, 2008; Ernst et al., 2005; Martins et al., 2006; Mendes et al., 2004). Despite a more stable environment, around $600 \mathrm{cal}$. yr BP, a change seemed to occur, as the number of benthic foraminifera reached a minimum and some species such as $A$. beccarii and E. scaber presented peaks of abundance. Ammonia beccarii is a typical estuarine species from the Guadiana estuary (Ruiz et al., 2005) and E. scaber shows a higher abundance near the Guadiana River mouth (Mendes et al., 2004). 
The highest abundances of these species, associated with a smooth peak of gravel and sand (c. 650 cal. yr BP), could be related to a wetter phase such as that identified by Abrantes et al. (2005), Lebreiro et al. (2006) and Alt-Epping et al. (2009) in the Tagus prodelta and by Bernárdez et al. (2008) on the Galician continental shelf interpreted as the beginning of the 'Little Ice Age' (LIA). Negative NAO indices were correlated with precipitation-river input during cold periods, and more persistent negative state or frequent extreme NAO minima occurred during the LIA (Abrantes et al., 2005; Lebreiro et al., 2006). According to Dias et al. (2004), discharges from the Guadiana River in the last 50 years show a strong link with the NAO index, with negative values usually resulting in higher rainfall and subsequent flooding in the river basin during winter months. Furthermore, the great interannual variability in the flows of the Tagus and Guadiana Rivers is largely modulated by the NAO phenomenon (Trigo et al., 2004). Deterioration of climate and intensification of rains combined with human activities would generate transportation of both coarser sediments and related foraminiferal species which are more abundant near the river mouth, to more distal areas of the inner shelf, where core 8 is located. These results are in agreement with those obtained by Bartels-Jónsdóttir et al. (2006) in the Tagus prodelta, where shifts in the benthic foraminiferal assemblages around $550 \mathrm{cal}$. yr BP were associated with increased river discharges.

The highest sedimentation rates, together with the stabilization of the fine fraction deposition in core 8 on the inner shelf prodeltaic wedge (at c. $1400 \mathrm{cal}$. yr BP until present) and in core 5 on the middle shelf mud body (from c. 900 to $c .420$ cal. yr BP) (Figure 2a, c), could be related with increased settlement density. According to Boone and Worman (2007), after the dissolution of the Roman control of Iberia in the 5th century AD (c. 1500 cal. yr BP) and over the next 500 years, particularly after the Muslim invasion of $\mathrm{AD} 711$ (c. 1200 cal. yr BP), settlement density increased six-fold over the number of inhabitants in the Roman period.

On the central Adriatic Sea, sedimentation rates roughly quadrupled between 1100 and $700 \mathrm{yr} \mathrm{BP}$ in response to land use changes, which increased the input of terrigenous sediment to the shelf (Oldfield et al., 2003). In the region of Mértola (approximately $70 \mathrm{~km}$ upriver from the estuary mouth) geoarchaeological investigation concerning the role of human activity and environmental change points to widespread erosion and soil loss after the later Medieval Islamic period (800-900 cal. yr BP), caused by the overuse of land (Boone and Worman, 2007). This probably led to the increased exportation of sediments to the shelf, which contributed to the silting-up of the Guadiana's eastern distributary. The reinforcement of the western distributary, with the transportation of greater amounts of sediments to the shelf, led to the formation of the present prodeltaic wedge. On the middle shelf, the establishment of the muddy body where the higher rates of sedimentation were observed seems to have occurred only after the formation of the prodeltaic wedge.

\section{Conclusions}

This study allowed an integrated approach, on the paleoenvironmental evolution of the continental shelf off Guadiana River in response to natural and human-induced changes. Four evolutionary stages were identified. Each stage is a representation of the environmental changes that characterized the three depositional environments at different times during the Holocene. They indicate that the three older stages were mainly influenced by natural processes, including sea level changes, influence of river discharge and substrate properties. The younger stage, the last $c$. 1500 cal. yr BP, reflects human-induced environmental changes caused by human occupation (inducing soil erosion) associated with climatic changes.

The three shelf environments studied differed in terms of depth, sedimentary regime, and benthic foraminiferal assemblages, however, dominated by sand from fluvial origin. On the basis of these variations four evolutionary stages were identified. The first stage from $c .11,500$ to $c .10,000 \mathrm{cal}$. yr BP, on the middle shelf mud body (Core 5) was characterized by a deepening sedimentary environment with high influence of river discharges. The upper middle shelf transgressive bulge (Core 7) was probably located in the vicinity of the paleo-mouth of the Guadiana River. The second stage from $c .10,000$ to $c .5000$ cal. yr BP reflected the reduction of sediments exported to the shelf, as result of the continuous and rapid sea level rise and consequent estuary infilling. On the transgressive bulge, this period reflected a shallower environment influenced by Guadiana River discharges. The present day sea level was reached in the beginning of third stage from $c$. 5000 to $c$. $1500-1000$ cal. yr BP. This period reflects depositional conditions that established the muddy body, after the attainment of the present mean sea level and of estuary equilibrium. On the prodeltaic wedge the sedimentary deposition occurred under the direct influence of the easternmost distributary of the Guadiana River. The forth stage from $c$. $1500-1000$ cal. yr BP to Recent times, reflects the intensification of human activities, the muddy body formation and recent depositional conditions. On the prodeltaic wedge, after 1200 cal. yr BP, new climatic and environmental conditions were established. However, around c. $600 \mathrm{cal}$. yr BP, a wetter phase, related to the beginning of the LIA, may have been registered. This phase could also be associated with negative NAO values, which would likely have resulted in more rainfall and subsequent flooding in the river basin during winter months. The intensification of human impact on the Guadiana River basin, associated with more humid climate conditions led to an increase in sediment export to the shelf and to the possible silting-up of the Guadiana's eastern distributary. The reinforcement of the western distributary, led to the formation of the present prodeltaic wedge. On the middle shelf, the establishment of the muddy body seems to have occurred only after the prodeltaic wedge formation.

\section{Funding}

This work was supported by the Portuguese Science Foundation under the aims of projects CRIDA (Consequences of River Discharge Modifications on Coastal Zones and Continental Shelf - PDCTM/P/MAR/15289/1999); IMCA (Impact of climatic and anthropic variations on the northern continental shelf, Gulf of Cadiz - POCTI/CLI/60192/2004) and CIRCO (Climate changes from isotopic records during the Holocene in South-western Iberia - PTDC/CLI/66393/2006). Isabel Mendes thanks also the Portuguese Science Foundation for grants SFRH/BD/18342/2004 and SFRH/BPD/72869/2010 and Francisca Rosa for grant SFRH/ $\mathrm{BD} / 46020 / 2008$.

\section{References}

Abrantes F, Lebreiro S, Rodrigues T et al. (2005) Shallow-marine sediment cores record climate variability and earthquake activity off Lisbon (Portugal) for the last 2000 years. Quaternary Science Reviews 24: 2477-2494.

Alarcão J (1988) O Domínio Romano em Portugal. Mem Martins: Publicações Europa-América.

Alt-Epping U, Stuut J-BW, Hebbeln D et al. (2009) Variations in sediment provenance during the past 3000 years off the Tagus River, Portugal. Marine Geology 261: 82-91.

Altenbach AV and Sarnthein M (1989) Productivity record in benthic foraminifera. In: Berger WH, Smetacek VS and Wefer G (eds) Productivity of the Oceans: Past and Present. Chichester: Wiley-Interscience, pp. 255-269.

Alve E (2003) A common opportunistic foraminiferal species as an indicator of rapidly changing conditions in a range of environments. Estuarine, Coastal and Shelf Science 57: 501-514. 
Bartels-Jónsdóttir HB, Knudsen KL, Abrantes F et al. (2006) Climate variability during the last 2000 years in the Tagus Prodelta, western Iberian Margin: Benthic foraminifera and stable isotopes. Marine Micropaleontology 59: 83-103.

Bauch H, Kassens H, Naidina O et al. (2001) Composition and flux of Holocene sediments on Eastern Laptev Sea Shelf, Arctic Siberia. Quaternary Research 55: 344-351.

Bennett KD (2005) Psimpoll Manual. http:/www.kv.geo.uu.se/psimpoll.html.

Bernárdez P, González-Álvarez R, Francés G et al. (2008) Late Holocene history of the rainfall in the NW Iberian peninsula - Evidence from a marine record. Journal of Marine Systems 72: 366-382.

Boone JL and Worman FS (2007) Rural settlement and soil erosion from the late Roman Period through the medieval Islamic Period in the lower Alentejo of Portugal. Journal of Field Archaeology 32: 115-132.

Boski T, Moura D, Veiga-Pires C et al. (2002) Postglacial sea-level rise and sedimentary response in the Guadiana Estuary, Portugal/Spain border. Sedimentary Geology 150: 103-122.

Burdloff D, Araújo MF, Jouanneau JM et al. (2008) Sources of organic carbon in the Portuguese continental shelf sediments during the Holocene period. Applied Geochemistry 23: 2857-2870.

Chester DK and James PA (1999) Late Pleistocene and Holocene landscape development in the Algarve Region, Southern Portugal. Journal of Mediterranean Archaeology 12: 169-196.

Corredeira C, Araújo MF and Jouanneau JM (2008) Copper, zinc and lead impact in SW Iberian shelf sediments: An assessment of recent historical changes in Guadiana river basin. Geochemical Journal 42: 319-329.

Costa C (1994) Wind-Wave Climatology of the Portuguese COSAT. Final Report of Sub-Project A., NATO PO-WAVES Report 6/94-A, 80.

Costa M, Silva R and Vitorino J (2001) Contribuição para o estudo do clima de agitação marítima na costa portuguesa. 2 as Jornadas de Engenharia Costeira e Portuária, Aveiro: AIPCN, 20.

de Nooijer LJ, Duijnstee IAP, Bergman MJN et al. (2008) The ecology of benthic foraminifera across the Frisian Front, southern North Sea. Estuarine, Coastal and Shelf Science 78: 715-726.

de Rijk S, Jorissen FJ, Rohling EJ et al. (2000) Organic flux control on bathymetric zonation of Mediterranean benthic foraminifera. Marine Micropaleontology 40: 151-166.

Dias JMA, Boski T, Rodrigues A et al. (2000) Coast line evolution in Portugal since the Last Glacial Maximum until present - A syntheesis. Marine Geology 170: 177-186.

Dias JMA, Gonzalez R and Ferreira Ó (2004) Natural versus anthropic causes in variations of sand export from river basins: An example from the Guadiana river mouth (southwestern Iberia). Polish Geological Institute Special Papers 11: 95-102.

Diz P and Francés G (2008) Distribution of live benthic foraminifera in the Ría de Vigo (NW Spain). Marine Micropaleontology 66: 165-191.

Diz P, Francés G, Pelejero C et al. (2002) The last 3000 years in the Ría de Vigo (NW Iberian Margin): Climatic and hydrographic signals. The Holocene 12: 459-468

Donnici S and Barbero RS (2002) The benthic foraminiferal communities of the northern Adriatic continental shelf. Marine Micropaleontology 44: 93-123.

Duchemin G, Fontanier C, Jorissen FJ et al. (2007) Living small-sized (63-150 $\mu \mathrm{m}$ ) foraminifera from mid-shelf to mid-slope environments in the Bay of Biscay. Journal of Foraminiferal Research 37: 12-32.

Ellis BF and Messina AR (1942-2009) Catalogue of Foraminifera. Micropaleontological Press: Bulletin of the American Museum of Natural History.

Ernst S, Bours R, Duijnstee I et al. (2005) Experimental effects of an organic matter pulse and oxygen depletion on a benthic foraminiferal shelf community. Journal of Foraminiferal Research 35: 177-197.

Evans JR, Austin WEN, Brew DS et al. (2002) Holocene shelf sea evolution offshore northeast England. Marine Geology 191: 147-164.

Fabião C (1992) O passado Proto-Histórico e Romano. A Romanização do actual território português. In: Mattoso J (ed.) História de Portugal, direcção de José Mattoso. Círculo de Leitores, 567 pp.

Fairbanks RG (1989) A 17,000-year glacio-eustatic sea level record: Influence of glacial melting rates on the Younger Dryas event and deep-ocean circulation. Nature 342: 637-642.

Fleming K, Johnston P, Zwartz D et al. (1998) Refining the eustatic sea-level curve since the Last Glacial Maximum using far- and intermediate-field sites. Earth and Planetary Science Letters 163: 327-342.

Fletcher WJ, Boski T and Moura D (2007) Palynological evidence for environmental and climatic change in the lower Guadiana valley, Portugal, during the last 13000 years. The Holocene 17(4): 481-494.

Folk RL (1954) The distinction between grain size and mineral composition in sedimentary-rock nomenclature. Journal of Geology 62(4): 344-359.
Frezza V and Carboni MG (2009) Distribution of recent foraminiferal assemblages near the Ombrone River mouth (Northern Tyrrhenian Sea, Italy). Revue de Micropaléontologie 52: 43-66.

Gonzalez R and Dias JA (2006) Sediment dispersal patterns on the northern Gulf of Cadiz Shelf: Which areas are influenced by anthropogenic sand starvation? Journal of Coastal Research SI 39: 572-577.

Gonzalez R, Dias JA and Ferreira Ó (2001) Recent rapid evolution of the Guadiana estuary (south western Iberian Peninsula) Journal of Coastal Research SI 34: 516-527.

Gonzalez R, Dias JA and Ferreira Ó (2005) Analysis of landcover shifts in time and their significance: An example from the Mouth of the Guadiana Estuary (SW Iberia). In: FitzGerald D and Knight J (eds) High-Resolution Investigations of the Morphodynamics and Sedimentary Evolution of Estuaries. Dordrecht: Springer, pp. 57-82.

Gonzalez R, Dias JA, Lobo F et al. (2004) Sedimentological and paleoenvironmental characterisation of transgressive sediments on the Guadiana Shelf (Northern Gulf of Cadiz, SW Iberia) Quaternary International 120: 133-144.

Hald M, Kolstad V, Polyak L et al. (1999) Late-glacial and Holocene paleoceanography and sedimentary environments in the St. Anna Trough, Eurasian Arctic Ocean margin. Palaeogeography, Palaeoclimatology, Palaeoecology 146: 229-249.

Hammer Ø, Harper DAT and Ryan PD (2008) PAST - PAlaeontological STatistics, ver. 1.81. http://folk.uio.no/ohammer/past/.

Hijma MP and Cohen KM (2010) Timing and magnitude of the sea-level jump preluding the $8200 \mathrm{yr}$ event. Geology 38: 275-278.

Jiang H, Björck S and Knudsen KL (1997) A palaeoclimatic and palaeoceanographic record of the last $11000{ }^{14} \mathrm{C}$ years from the Skagerrak-Kattegat, northeastern Atlantic margin. The Holocene 7: 301-310.

Jones RW (1994) The Challenger Foraminifera. London: Oxford University Press.

Jorissen FJ (1987) Distribution of benthic foraminifera in the Adriatic Sea. Marine Micropaleontology 12: 21-48.

Kaiho K (1999) Effect of organic carbon flux and dissolved oxygen on the benthic foraminiferal oxygen index (BFOI). Marine Micropaleontology 37: 67-76.

Kaminski MA, Aksu A, Box M et al. (2002) Late Glacial to Holocene benthic foraminifera in the Marmara Sea: Implications for Black Sea Mediterranean Sea connections following the last deglaciation. Marine Geology 3162: 1-37.

Lamb HH (1977) Climatic History and the Future. Climate: Present, Past and Future. Princeton: Princeton University Press.

Lantzsch H, Hanebuth TJJ and Bender VB (2009) Holocene evolution of mud depocentres on a high-energy, low-accumulation shelf (NW Iberia). Quaternary Research 72: 325-336.

Lebreiro SM, Francés G, Abrantes FFG et al. (2006) Climate change and coastal hydrographic response along the Atlantic Iberian margin (Tagus Prodelta and Muros Ría) during the last two millennia. The Holocene 16: 1003-1015.

Lesueur P, Tastet JP and Marambat L (1996) Shelf mud fields formation within historical times: Examples from offshore the Gironde estuary, France. Continental Shelf Research 16: 1849-1870.

Levy A, Mathieu R, Poignant A et al. (1995) Foraminiferes actuels de la Marge Continentale Portugaise - Inventaire et Distribuition. Lisboa: Memórias do Instituto Geológico e Mineiro.

Lobo FJ, Hernández-Molina FJ, Somoza L et al. (2001) The sedimentary record of the post-glacial transgression on the Gulf of Cadiz continental shelf (Southwest Spain). Marine Geology 178: 171-195.

Lobo FJ, Sánchez R, González R et al. (2004) Contrasting styles of the Holocene highstand sedimentation and sediment dispersal systems in the northern shelf of the Gulf of Cadiz. Continental Shelf Research 24: 461-482.

Loeblich AR and Tappan H (1987) Foraminiferal Genera and their Classification. New York: Van Nostrand Reinhold.

Loureiro JJM, Nunes MNF and Machado MLR (1986). A Bacia Hidrográfica do Rio Guadiana. In: M.P.A.T., S.E.A.R.N., Monografias Hidrológicas dos Principais Cursos de Água de Portugal Continental. Direcção Geral dos Recursos e Aproveitamentos, pp. 341-407.

Maldonado A and Nelson CH (1999) Interaction of tectonic and depositional processes that control the evolution of the Iberian Gulf of Cadiz margin. Marine Geology 155: 217-242.

Martins V and Gomes V (2004) Foraminiferos da Margem Continental NW Ibérica, Sistemática, Ecologia e Distribuição. Agenda Comum - Comunicação lda.

Martins V, Dubert J, Jouanneau JM et al. (2007) A multiproxy approach of the Holocene evolution of shelf-slope circulation on the NW Iberian Continental Shelf. Marine Geology 239: 1-18. 
Martins V, Jouanneau JM, Weber O et al. (2006) Tracing the late Holocene evolution of the NW Iberian upwelling system. Marine Micropaleontology 59: $35-55$.

Mendes I, Gonzalez R, Dias JMA et al. (2004) Factors influencing recent benthic foraminifera distribution on the Guadiana shelf(Southwestern Iberia). Marine Micropaleontology 51: 171-192.

Mendes I, Rosa F, Dias JA et al. (2006) Holocene evolution of the Continental Shelf off Guadiana River, SW Iberian Peninsula. In: Rocha F, Terroso D and Santos A (eds) 5th Symposium on the Iberian Atlantic Margin. Aveiro, Portugal, 2-4 November. Universidade de Aveiro, pp. 141-142.

Mendes I, Rosa F, Dias JA et al. (2010) Inner shelf paleoenvironmental evolution as a function of land-ocean interactions in the vicinity of the Guadiana River, SW Iberia. Quaternary International 221: 58-67.

Mojtahid M, Jorissen F, Lansard B et al. (2009) Spatial distribution of live benthic foraminifera in the Rhône prodelta: Faunal response to a continentalmarine organic matter gradient. Marine Micropaleontology 70: 177-200.

Morales JA (1997) Evolution and facies architecture of the mesotidal Guadiana River delta (S.W. Spain-Portugal). Marine Geology 138: 127-148.

Morigi C, Jorissen FJ, Fraticelli S et al. (2005) Benthic foraminiferal evidence for the formation of the Holocene mud-belt and bathymetrical evolution in the central Adriatic Sea. Marine Micropaleontology 57: 25-49.

Murray J (1971) An Atlas of British Tecent Foraminiferids. London: Heinemann Educational Books.

Murray J (2006) Ecology and Applications of Benthic Foraminifera. Cambridge: Cambridge University Press.

Nelson CH, Baraza J, Maldonado A et al. (1999) Influence of the Atlantic inflow and Mediterranean outflow currents on Late Quaternary sedimentary facies of the Gulf of Cadiz continental margin. Marine Geology 155: 99-129.

Nocete F, Álex E, Nieto JM et al. (2005) An archaeological approach to regional environmental pollution in the south-western Iberian Peninsula related to Third millennium BC mining and metallurgy. Journal of Archaeological Science 32: 1566-1576.

Odin GS and Matter A (1981) De glauconiarum origine. Sedimentology 28 : 611-641.

Oldfield F, Asioli A, Accorsi CA et al. (2003) A high resolution late Holocene palaeo environmental record from the central Adriatic Sea. Quaternary Science Reviews 22: 319-342.

Peltier WR and Fairbanks RG (2006) Global glacial ice volume and Last Glacial Maximum duration from an extended Barbados sea level record. Quaternary Science Reviews 25: 3322-3337.

Pessanha LE and Pires HO (1981) Elementos sobre o clima de agitação maritima na costa sul do Algarve. Lisboa: Instituto Nacional de Meteorologia e Geofísica, 66 pp.

Pinheiro J, Mendes I, Ferreira Ó et al. (2006) Dinâmica sedimentar da plataforma interna adjacente ao Rio Guadiana nos últimos 5000 anos. In Rocha F, Terroso D and Santos A (eds) 5th Symposium on the Iberian Atlantic Margin. Aveiro, Portugal, 2-4 November. Universidade de Aveiro, pp. 165-166.

Portela LI (2006) Sediment delivery from the Guadiana estuary to the coastal ocean. Journal of Coastal Research SI 39: 1819-1823.

Pujos M (1976) Écologie des foraminifères benthiques et des thecamoebiens de la Gironde et du plateau continental sud-Gascongne. Aplication à la connaissance du Quaternaire terminal de la région ouest-Gironde. Mémoire Institut Geologique Bassin D'Aquitaine, Bordeaux, 314 pp.

Roberts N (1998) The Holocene: An environment History. Oxford: Blackwell Publishers.

Rosa F, Dias JA, Mendes I et al. (2011) Mid to late Holocene constraints for continental shelf mud deposition in association with river input: The Guadiana Mud Patch (SW Iberia). Geo-Marine Letters: 31: 109-121.
Rossi V and Vaiani SC (2008) Benthic foraminiferal evidence of sediment supply changes and fluvial drainage reorganization in Holocene deposits of the Po Delta, Italy. Marine Micropaleontology 69: 106-118.

Ruiz F, González-Regalado ML, Pendón JG et al. (2005) Correlation between foraminifera and sedimentary environments in recent estuaries of Southwestern Spain: Applications to holocene reconstructions. Quaternary International 140-141: 21-36.

Samir AM and El-Din AB (2001) Benthic foraminiferal assemblages and morphological abnormalities as pollution proxies in two Egyptian bays. Marine Micropaleontology 41: 193-227.

Sarnthein M (1971) Oberflächensedimente im Persischen Golf und Golf von Oman, 11. Quantitative Komponentenanalyse der Grobfraktion. 'Meteor' Forschungs-Ergebnisse 5: 1-113.

Scourse JD, Austin WEN, Long BT et al. (2002) Holocene evolution of seasonal stratification in the Celtic Sea: Refined age model, mixing depths and foraminiferal stratigraphy. Marine Geology 191: 119-145.

Soares AMM and Martins JMM (2010) Radiocarbon dating of marine samples from Gulf of Cadiz: The reservoir effect. Quaternary International 221: 9-12.

Stanley DJ (1995) A global sea-level curve for the late Quaternary: The impossible dream? Marine Geology 125: 1-6.

Stuiver M and Reimer PJ (1993) Extended 14C database and revised CALIB radiocarbon calibration program. Radiocarbon 35: 215-230.

Stuiver M, Reimer PJ and Reimer RW (2005) CALIB Radiocarbon calibration ver. 5.0.1. http://calib.qub.ac.uk/calib/.

Teixeira SB, Gaspar P and Rosa M (2005) Holocene sea-level index points on the Quarteira Coast (Algarve, Portugal). In: Freitas MC and Drago T (eds) Coastal Hope. Lisbon, 125-127.

Trigo RM, Pozo-Vázquez D, Osborn TJ et al. (2004) North Atlantic Oscillation influence on precipitation, river flow and water resources in the Iberian Peninsula. International Journal of Climatology 24: 925-944.

van Geen A, Adkins JF, Boyle EA et al. (1997) A 120 yr record of widespread contamination from mining of the Iberian pyrite belt. Geology 25: 291-194.

Velozo FJ and Cardoso J (1965) Strabo - Geographica III, 1, 9. Primeira Contribuição para uma Nova Edição Critica. Colecção Amphitheatrum no. IX, Centro de Estudos Humanisticos, Porto: Universidade do Porto. Translation.

Villanueva PG and Cervera JLC (1999a) The recent uvigerinids (benthic foraminifera) in the northeastern Gulf of Cadiz Boletín Instituto Español de Oceanografia 15: 191-202.

Villanueva PG and Cervera JLC (1999b) Distribution of Planorbulinacea (benthic framinifera) assemblages in surface sediments on the northen margin of Gulf of Cadiz. Boletin Instituto Español de Oceanografia 15: 181-190.

Villanueva PG, Canudo JIS and Cervera JLC (1999) Los Foraminíferos Bentónicos Recientes de la Superfamilia Miliolacea Ehrenberg, 1836 en los Sedimentos Superficiales del Margen Septentrional del Golfo de Cádiz. Revista Española de Micropaleontología 31: 99-122.

Vis G-J, Kasse C and Vandenberghe J (2008) Late Pleistocene and Holocene palaeogeography of the Lower Tagus Valley (Portugal): Effects of relative sea level, valley morphology and sediment supply. Quaternary Science Reviews 27: 1682-1709.

Wollenburg JE, Mackensen A and Kuhnt W (2007) Benthic foraminiferal biodiversity response to a changing Arctic palaeoclimate in the last 24.000 years. Palaeogeography, Palaeoclimatology, Palaeoecology 255: 195-222.

Xiang R, Yang Z, Saito Y et al. (2008) Paleoenvironmental changes during the last 8400 years in the southern Yellow Sea: Benthic foraminiferal and stable isotopic evidence. Marine Micropaleontology 67: 104-119.

Zazo C, Dabrio CJ, Goy JL et al. (2008) The coastal archives of the last $15 \mathrm{ka}$ in the Atlantic-Mediterranean Spanish linkage area: Sea level and climate changes. Quaternary International 181: 72-87. 